\title{
Foreign bias in bond portfolio investments: the role of economic and non-economic factors and the impact of the global financial and sovereign debt crises
}

Bibek Bhatta, Andrew Marshall and Chandra Thapa

This is an Accepted Manuscript of an article published by Taylor \& Francis in The European Journal of Finance on 30th June 2017, available online: http://dx.doi.org/10.1080/1351847X.2017.1343199 


\title{
Foreign bias in bond portfolio investments: The role of economic and non-economic factors and the impact of the global financial and sovereign debt crises
}

\author{
Bibek Bhatta $^{a^{*}}$, Andrew Marshall ${ }^{\mathrm{b}}$, Chandra Thapa ${ }^{\mathrm{b}}$ \\ aivision of Accounting, Finance, Economics and Law, Dundee Business School, Abertay \\ University, United Kingdom DDI $1 H G$ \\ ${ }^{\mathrm{b}}$ Department of Accounting and Finance, Strathclyde Business School, Strathclyde University, \\ United Kingdom G1 $1 X Q$
}

This version: February 2017

\begin{abstract}
In this study we examine whether theoretically inconsistent foreign bond allocations are associated with economic fundamentals and/or non-economic behavioural factors. Using panel data for 54 developed and emerging markets spanning a temporal period of 12 years, the results show that non-economic factors, i.e. familiarity with foreign markets and behavioural characteristics of source markets, are the stronger drivers of biases in foreign bond allocations. Further, using the recent 2009-11 European sovereign debt crisis as an experimental set-up, we find that investors reduce their foreign bond allocations during the debt crisis, with the withdrawals being more severe from the most affected countries. We also find that the relevance of familiarity with foreign markets becomes more pronounced during the European debt crisis. However, in case of the recent 2007-09 global financial crisis, we find no evidence of change in foreign bias by international bond investors.
\end{abstract}

JEL Classification: G02, G11, G15

Key Words: Foreign bias in international bond allocations; Economic and non-economic factors; Global financial crisis; Sovereign debt crisis

\footnotetext{
* Corresponding Author. b.bhatta@abertay.ac.uk, Tel.: +44 (0)1382 308000

E-mail addresses a.marshall@strath.ac.uk; chandra.thapa@strath.ac.uk
} 


\section{Introduction}

Although contrary to finance theory, it is well established that portfolio investors overinvest in their domestic markets and underinvest in foreign markets, leading to investment biases. Most of the existing studies explaining these biases focus on equity investments, particularly explaining the cross-country differences in overweighting of domestic equities, referred to as equity home bias (Cooper and Kaplanis 1994; Grinblatt and Keloharju 2001). The issue of underweighting of foreign markets, referred to as foreign bias, ${ }^{1}$ has received much less attention. It focuses mainly on equity investments (Chan et al 2005; Beugelsdijk and Frijns 2010) and there is disagreement on the possible causes. For the first time to our knowledge, we explore the relative relevance of ecnomic and non-economic determinants of biases in foreign bond investments, examining their behaviour during the global financial and European debt crises.

In addition to filling the research gap on foreign bias, particularly on bonds, our study on the international allocation of bonds is also motivated by the importance, development and characteristics of the bond market. The size of global bond markets is roughly twice the size of equity markets. ${ }^{2}$ Further, it has witnessed steady growth in the past decade, as debt has become an important source of finance for governments, financial institutions and corporates. ${ }^{3}$ Despite such significant increases in the absolute dollar value of cross-border bond investments, the data reveals that bond investors are still not diversifying internationally to benefit from the optimal risk-return trade-off.

\footnotetext{
${ }^{1}$ In this paper, we follow the general terminology and denote relatively higher foreign investment in a foreign market as positive foreign bias and relatively lower foreign investment in a foreign market as negative foreign bias.

${ }^{2}$ See McKinsey and Company (2011) for comparative size of equity and debt markets.

${ }^{3}$ Data from Bank for International Settlements (BIS) show that bond market size increased from USD 35.5 trillion in year 2001 to USD 97.5 trillion in 2012. During the corresponding period, cross-border holdings of long-term debt (excluding money market instruments) grew from USD 5.5 trillion to USD 19.8 trillion, as reported by International Monetary Fund (IMF) in its Coordinate Portfolio Investment Survey (CPIS).
} 
Bonds also have unique characteristics relative to equity as asset class, and therefore the underlying determinants of bond foreign biases could be different from that observed in equity investments. For example, compared to equity markets, bonds exhibit lower volatility returns with a higher element of relative safety. ${ }^{4}$ Studies likewise show that government bond returns are not influenced by the same factors that impact equity returns (Elton 1999). Similarly, Campbell and Taksler (2003) report that the price of bonds can significantly diverge from that of equities, implying that different factors could drive the attractiveness of equities and bonds asymmetrically. These differential factors, along with their growing size and importance in the world economy, motivate us to examine whether it is the economic fundamentals or non-economic factors that are more influential in international bond investment bias. ${ }^{5}$ Further, there is evidence that investors do not flee volatility in equity markets but do take flight from volatility in bond markets (Burger and Warnock 2003). Therefore, we investigate whether there were any significant reallocations of bond investments from countries most affected by the recent Eurozone sovereign debt crisis. Additionally, the setting of debt crisis along with recent global financial crisis, allows us to test whether the sensitivity of economic and non-economic factors is different during periods of economic crisis relative to non-crisis periods.

In summary, we examine three important issues related to foreign bond investments. First, we investigate whether it is the economic fundamentals and/or non-economic factors that are associated with biases in foreign bond allocations. Second, using the 2009-11 European sovereign debt and 2007-09 global financial crises as experimental set-ups, we investigate whether investors reallocate/rebalance their bond portfolio during these turbulent economic

\footnotetext{
${ }^{4}$ Government bonds, as of 2011, occupy approximately $45 \%$ of global bond market (McKinsey and Company 2011).

${ }^{5}$ We use the term 'non-economic' in a narrow sense to include bilateral familiarity and source country-specific behavioural factors unless there is a need to discuss these two categories separately. As discussed in Section 2.2, we capture bilateral familiarity using country-pair language, distance, and trade (Chan et al 2005). Our source country-specific behavioural factors are related to uncertainty avoidance and masculinity.
} 
periods. Third, we examine whether the crises periods interact with economic and noneconomic factors and their effect on driving biases in foreign bond allocations.

Using an extensive dataset on cross-border bond allocations for 54 markets (developed and emerging) spanning 12 years, two important findings emerge from our study. First, though economic fundamentals and non-economic factors (including familiarity and behavioural factors) both are important drivers of foreign bias, we find that familiarity, which tends to lower information acquisition costs with foreign markets, is the predominant driver of foreign bias. Given the lower volatility of bond market, the premium attached by foreign investors for economic fundamentals (including institutional factors) seems to be of secondary importance relative to familiarity with foreign markets. Further, in addition to the bilateral familiarity factors, non-economic investor-specific behavioural attributes also offer interesting insights in the allocations decisions of cross-country bond investments. We find that investors with higher levels of uncertainty avoidance consistently underweight foreign bond markets. In contrast, investors with higher levels of masculinity, a proxy for competitiveness, have greater allocation of funds invested in foreign bonds.

Second, during the 2007-09 global financial crisis we find no statistical evidence of lower foreign bond diversification from all foreign countries. This can be explained by the global systematic nature of the crisis, where foreign bond markets were not as severely affected globally (in comparison to other asset classes) and with respect to individual regions or countries. However, when we include the period spanning the European debt crisis and in particular, focus on the markets most severely affected, i.e. Greece, Italy, Ireland, Portugal and Spain (GIIPS), we find that foreign investors divest their share of relative allocations from the markets suffering most from the European debt crisis. Further, we also find that the importance of non-economic factors in explaining foreign bias is even greater during the European debt crisis, even after controlling for economic factors. 
Our study contributes to the following three strands of the literature. First, we add to the limited literature on international bond portfolio diversification. Our study is related to De Moor and Vanpee (2013) but to the best of our knowledge, this is the first study to simultaneously investigate the relative importance of economic fundamentals versus behaviourally influenced non-economic factors in explaining foreign biases in international bond allocations. ${ }^{6}$ Second, we also supplement the literature which associates the role of cultural attitude with foreign investment decisions ( Grinblatt and Keloharju, 2001, Graham et al., 2009 amongst others). Specially, we show how investor-specific cultural factors can influence foreign bond allocation decisions. Finally, we also contribute to the growing literature linking crisis periods and investor behaviour (Malmendier and Nagel 2011). We consider both the period of global financial crisis (2007-09) and the European sovereign debt crisis (2009-11) to examine how these periods influence foreign bias in international bond investment. Additionally, we consider whether the sensitivities of economic and non-economic factors can alter during the economic crisis periods relative to non-crisis periods.

The rest of the paper is structured as follows. The following section contains a brief discussion on the theoretical framework and possible determinants of foreign bias with their economic explanations. The subsequent section describes the data and variables. After this we provide the empirical analysis, and the final section concludes the paper.

\section{Deadweight Costs and Investment Biases}

\footnotetext{
${ }^{6}$ Other important differences in our paper is the inclusion of cultural attitudes of investors because investors are known to make decisions based on their personal or societal traits (see Chui and Kwok, 2008; Graham et al., 2009; Kaplanski et al., 2015; Kirkman et al., 2006; Kwok and Tadesse, 2006). Also they examine equity and bond bias over 10 years without allowing for crisis periods. We focus on normal as well as economically turbulent crisis periods (both global financial crisis and Eurozone debt crisis) to enhance our understanding of the impact of different factors during these different times and provide some interesting results. We include additional tests related to this by segregating the data between EMU markets and non-EMU markets.
} 
Our theoretical framework is drawn from Cooper and Kaplanis (1986). The framework stipulates that investors, assuming that they intend to maximize their return for a given level of risk, hold the world market portfolio in the absence of deadweight costs, i.e. when all investors are not hindered by any form of barrier to invest in foreign markets. However, the presence of direct and indirect barriers to international investments, that generates marginal deadweight costs, translates into deviations from the world market portfolio. We segregate the factors driving bond investment biases into two categories. The first group is related to economic fundamentals and the second to non-economic factors. Economic fundamentals are linked to country-specific economic and institutional factors and non-economic issues are associated with information asymmetry and irrationality issues. We describe all the variables we use in our empirical analysis in Table I, explaining both economic and non-economic factors.

[Insert Table I here....]

\subsection{Economic Factors,Bond Allocation and Foreign Bias}

To capture different dimensions of economic drivers of bond allocations, we use a wide range of economic fundamentals. These include returns on bond investments, foreign exchange risks, bond market development, investor protection standards, explicit barriers of formal capital control, and other macroeconomic factors (Chan et al 2005; Bekaert and Wang 2009; Forbes 2010). Following our theoretical framework, we expect attractive features of foreign markets to reduce deadweight costs for investors thus leading to higher foreign bias. On the contrary, less attractive characteristics of a host market would lead to higher deadweight cost leading to lower foreign bias.

In terms of bond returns, the tendency of investors seeking higher returns by increasing holdings in well-performing assets has been widely examined (Chan et al 2005; Curcuru et al 2011). Based on this argument it is expected that recent higher market returns would motivate investors to increase their bond holding in that market, leading to higher foreign bias. 
Exchange rate volatility can increase deadweight costs for international investors (if bonds are issued in an overseas currency). Fidora et al (2007) find that investors are more likely to invest more in their domestic markets than investing abroad when faced with higher foreign exchange volatility. We anticipate that the higher exchange rate of a host market would make it less attractive for international bond investors, thus leading to lower foreign bias in that market.

Differential levels of bond market development across the globe can also generate deadweight costs for investors. Forbes (2010) finds that a country's financial market development positively influences foreign investment, as a well-developed market offers enhanced liquidity and efficiency. This suggests that a well-developed foreign market can attract international bond investors resulting in higher foreign bias.

With respect to investor protection, La Porta et al (1997) demonstrate that countries offering a lower level of investor protection have less developed capital markets lacking the optimal breadth and depth. Similarly, Bae et al (2006) find that foreigners invest more in bonds of those countries that safeguard investors' property rights. As a result, within our framework, the higher degree of investor protection standards in a host market generates lower degree of deadweight costs for international bond investors, thus leading to higher foreign bias.

Although capital controls have been progressively relaxed over the past few decades (McLeavy and Solnik 2014), the degree of openness still varies across countries. Higher levels of capital control impose limits on foreign investors on their investments in national markets (Ahearne et al 2004). This implies that relaxing capital account restrictions and easing existing barriers to capital inflows would increase foreign investments in a given market (Chan et al 2005; Forbes 2010). Therefore we expect a higher level of capital openness to be associated with higher foreign bias. 
Macroeconomic imbalances and, financial and political risks could also explain foreign biases as they are associated with generating higher deadweight costs to foreign investors (Bekaert et al 2014; Afonso et al 2015). For instance, Eurozone countries struggling to bring their budget deficits within agreed levels could be indicators of future shocks in their bond markets, making those host countries less attractive for bond investors. To control for a wide spectrum of such risks, not included in other variables, we add country credit ratings in our analysis. We expect that higher country risk should discourage foreign investors leading to lower foreign bias.

\subsection{Non-economic Factors, Bond Allocation and Foreign Bias}

It is suggested that higher familiarity of an asset/market leads to more investment in that asset/market (Huberman 2001). However, there is no conclusive consensus as to whether the effect of such familiarity is rational or irrational. For example, Chan et al (2005) equate higher familiarity to lower information costs, measuring the varying degree of information asymmetry between home and foreign investors, whereas Grinblatt and Keloharju (2001) associate familiarity bias with irrationality. Earlier studies also lend support to the non-economic and non-rational aspect of familiarity where investors are more optimistic about domestic asset returns as they feel less competent to evaluate foreign assets (Heath and Tversky, 1991). Given the disagreement in segregating the familiarity and behavioural issues, in this study we use several country-pair and source country investor-specific factors capturing the different sources of familiarity and/or irrationality under the common heading of "non-economic factors".

We are motivated to treat the bilateral pair country factors separately from economic fundamentals for two reasons. First, all the economic fundamentals are country-specific and the familiarity explanations are country-pair dependent. Second, all economic fundamentals are expected to impact investment biases directly on their own, but the bilateral links are expected to influence investment biases indirectly through familiarity with foreign markets. 
The first two factors we use are the geographic proximity between source and host countries and a dummy variable reflecting whether investors share a common language in the countrypair. In terms of distance, Chan et al (2005) suggest that international investors are more reluctant to invest in countries that are relatively further away. Higher geographical distance creates larger deadweight costs arising from lower familiarity, which in turn leads to lower foreign bias (i.e. less favourable foreign allocations). A similar argument applies to common language, however the impact is in the reverse direction, as sharing a common language with a foreign market helps in enhancing familiarity of host market thus motivating higher allocations (Cuypers et al., 2015; Grinblatt and Keloharju, 2001). Therefore we expect bond investors to favour foreign markets that share a common language. The third factor known to capture time-varying degree of familiarity between country pairs is bilateral trade (Lane and Milesi-Ferretti 2008). The flow of information through trade increases familiarity with partner countries and therefore would increase foreign bias.

We complement the bilateral familiarity factors with two source country-specific behavioural factors. The first is related to varying level of uncertainty avoidance among investors from different countries, and the second factor is associated with investors' drive for competitiveness and material rewards. Countries where investors have higher levels of uncertainty avoidance are known to have greater bank-dominated (less risky) financial markets, whereas countries with lower levels of uncertainty avoidance are known to be more marketdominated (more risky) (Kwok and Tadesse 2006). Empirically, Anderson et al (2011) find that countries with higher levels of uncertainty aversion diversify less in foreign equities, but they do not find outsiders being influenced by such behavioural characteristics of host country investors. On a similar note, Beugelsdijk and Frijns (2010) show that more uncertainty avoiding countries invest lower amounts in foreign equities, which is more pronounced for emerging markets. In summary, existing empirical evidence suggests that investors from countries that 
have relatively higher levels of uncertainty-aversion would be less inclined to invest in unfamiliar assets abroad and therefore underweight foreign bonds.

The second investor-specific behavioural factor is associated with the general view that some societies tend to be more competitive, assertive and reward-seeking than others (Hofstede 1980). Intuitively, investors from societies that place more preference to competition and material rewards should be more inclined to venture out of familiar territory in search of greater rewards. Empirical evidence also suggests that investors from such competitive and rewardseeking societies exhibit higher levels of foreign equity diversification, possibly because they perceive themselves to possess better information about foreign markets (Anderson et al 2011). Graham et al (2009) also show that investors who feel more competent invest a larger portion of their wealth in foreign assets. In line with this view we suggest that the tendency of a society to be more competitive, aggressive, and reward-seeking can drive investors to invest more in (foreign) markets they are less familiar with, and this might partially explain the biases observed in international bond diversification.

\section{Data}

In this section is we discuss our data and the construction of the variables that captures different aspects of economic and non-economic factors.

\subsection{Measure of Foreign Bias}

The construction of a foreign bias measure needs market level crossborder bond portfolio holdings and bond market size data. Crossborder bond holdings data are obtained from Coordinated Portfolio Investment Survey (CPIS) of International Monetary Fund. After cleaning the data $^{7}$ and based on the availability of data on bond market size, our yearly average

\footnotetext{
${ }^{6}$ The CPIS database has been used by Bekaert and Wang (2009) and Lau et al (2010) amongst others. However, a few caveats need to be noted in using the CPIS data set. For example, investment from some countries, (notably China) are not reported; some investments are shown as negative values; a small sample is reported as unallocated; some data is reported as confidential and investments from 'international organizations' are also reported. For the
} 
crossborder holdings figure over the sample period is approximately US\$10 trillion. Our sample includes 54 of the Morgan Stanley Capital International (MSCI) designated developed, emerging and frontier markets for the period of 2001-2012. ${ }^{8}$ In terms of temporal range in our sample, the cross-border bond holdings increased from US $\$ 3.7$ trillion in 2001 to US $\$ 14.3$ trillion in 2012. Further, the total cross-border investments received by our sample countries comprises of $76 \%$ of the average total holdings (US\$120 trillion for 2001-12 from a total of US $\$ 158$ trillion) reported by CPIS. Therefore we suggest that our sample is representative of the aggregate global bond market portfolio investments.

Following Fidora et al (2007), bond market size is taken from Table 14B, 16A and 18 from Debt Securities Statistics provided by BIS. Table 14B relates to all outstanding international bonds and notes, excluding money market instruments, issued by domestic issuers. Table 16A provides figures on outstanding domestic debt securities issued by domestic residents and Table 18 includes figures on total debt securities (domestic and international) issued by domestic residents. In case of difference in amount between table 18 and combined 14B plus 16A, we take the higher of the two. The average yearly global outstanding bond market figure for the sample countries is US\$63.8 trillion, with a temporal variation of US\$35.5 trillion in 2001 to US\$97.5 trillion in 2012.

To construct the foreign bias measures, we need to first compute the bilateral allocation made by investors from source country $i$ into bond portfolio issued by host country $j$ for the period $t$ as shown in the equation (1) below:

$$
w_{i j t}=B H_{i j t} / \sum_{j=1}^{54} B H_{i j t}
$$

\footnotetext{
purpose of foreign bias, we ignore the negative and unallocated cross-border investments. Following Cooper et al (2012) we replace all zero international investment as USD 1 to ensure that complete underinvestment in host markets are not ignored.

${ }^{8}$ The coverage of our sample period is dictated by the availability of data. For example, data on bond market development and capital openness is not yet available for the year 2013.
} 
where $w_{i j t}$ is the share of host country $(j)$ in bond holdings for investors of source country $(i)$ and $B H_{i j t}$ is the market value of bond holdings of country $j$ in the portfolio of country $i$ 's investors as reported by CPIS for period $t$. Next, the benchmark weight of country $j$ in the world market portfolio is calculated in equation (2) as follows:

$$
w_{j t}^{*}=M V_{j t} / \sum_{j=1}^{54} M V_{j t}
$$

where $w_{j t}^{*}$ is the share of country $j$ in world bond market and $M V_{j t}$ is the bond market outstanding of country $j$ for the period $t$ as obtained from BIS. We follow Chan et al (2005) to calculate foreign bias measure for each country pair. Foreign bias $\left(F B I A S_{i j t}\right)$, as defined in equation (3) below, is the extent to which investors from source country (i) overweight or underweight foreign markets $(j)$ in their bond holdings and is computed as the log ratio of $w_{i j t}$ to $w_{j t}^{*}$. In our empirical tests higher foreign bias indicates more weight of the host market.

$$
F B I A S_{i j t}=\ln \left(w_{i j t} / w_{j t}^{*}\right)
$$

\subsection{Economic Variables}

We use real annual yield (YLD), net of sovereign default risk premium and expected inflation, as a measure of bond returns. The annual yield on ten-year government bond is computed as the preceding twelve months' average yield. The data is obtained primarily from International Financial Statistics (IFS) of IMF. For some countries where this data is not available in IFS, we collect this data from Economic Intelligence Unit. Inflation figures (http://www.eiu.com/), based on CPI index, are from World Development Indicators (WDI) of the World Bank and sovereign default risk spreads based on Moody's ratings are taken from Damodaran's website. For five countries where local currency yields are not available from either source, we use yields from USD-denominated debt taken from JP Morgan's EMBI series net of country risk 
and US inflation. ${ }^{9}$ To capture exchange rate volatility $(E X C H)$, we use the 61-country tradeweighted and inflation-adjusted broad monthly indices for real effective exchange rate from BIS with year 2010 as the base year. We calculate yearly volatility as percentage change in the indices per year based on the preceding 36 months' data. In all our regressions, we take the natural $\log$ of exchange rate volatility for a given country.

To capture the overall bond market development, we use the sum of private domestic bonds and private international bonds taken as a share of GDP as a proxy for bond market development $(B D E V)$ and use it in its logarithmic form in our empirical analysis. ${ }^{10}$ The data is sourced from Global Financial Development Database developed by Cihak et al (2013). ${ }^{11}$ Our measure of property rights $(P R O P)$ is from Table 2c of Economic Freedom Network (EFN) (freetheworld.com/datasets_efw.html) compiled by Gwartney et al (2014) and ranges from 1 to 10 . Lower score implies that rights over financial and other assets are poorly defined and not properly protected by law whereas higher score represents clear definition and enhanced protection of such rights. As a measure of capital controls, we use the openness index (CAPOP) from the Table 4Dii of EFN. This measure ranges from 0-10, and is constructed on the basis of 13 different types of international capital controls measures reported in the various issues of Annual Report on Exchange Arrangements and Exchange Restrictions of IMF. A higher score reflects higher level of capital openness. Country risk (CRISK) measure is based on Moody's ratings and ranges from 0 to 1000 basis points with higher score representing higher risk. Following earlier studies (Eichengreen and Mody 2000; Cruces and Trebesch 2013), we do not use the absolute values, but regress such credit ratings against all the other economic

\footnotetext{
${ }^{9}$ The five countries are Argentina, Egypt, Indonesia, Turkey and Ukraine. Excluding these five countries from our sample does not change the findings of this paper.

${ }^{10}$ Burger and Warnock (2003) and Forbes (2010) use ratio of domestic bond market capitalization to GDP as a measure of overall bond market development. However, ignoring the international component of bond issuances ignores an important element of overall development of the bond market.

${ }^{11}$ This data is available only for the period 2000 to 2011 . However, since the temporal variation over any twoyear period is not significantly material, we use the data from 2011 for the year 2012.
} 
fundamentals and use the residuals in our equations. This residual captures all the other country-specific time-varying factors that we have not included in our set of economic variables but are used by credit rating agencies to assess the riskiness of the country.

\subsection{Non-Economic Variables}

Geographical proximity is measured by distance (DIST) in kilometres between capital cities of country pairs and is from Gleditsch (2014, www.essex.ac.uk/ ksg/) (natural logarithmic form in all regressions). ${ }^{12}$ Common language (COMLA) is a dummy variable with a value of one if a country pair shares major language with another country, taken from Wei and Subramaniyan (2007) (http://users.nber.org/ wei/data.html, see 'Dataset 2). Bilateral trade (BILTR) is the weight in international trade assigned to a given country by its partner countries. Figures on bilateral trade, including both exports and imports, are taken from IMF Direction of Trade Statistics.

For measures of source country-specific uncertainty avoidance, we take country level scores for uncertainty avoidance $(U N T A V)$ from Hofstede (1980). ${ }^{13}$ It measures the extent to which individuals in the country feel uncomfortable with ambiguous and uncertain situations. This measure is based on a scale of 0-100 with higher score indicating higher level of tendency to avoid uncertain and ambiguous situations. ${ }^{14}$ To measure the degree of competitiveness and reward-seeking tendency prevalent in a society, we use the country score for masculinity (MASC), also from Hofstede (1980). Higher score on this dimension implies that the society has an affinity for more assertiveness, competition, achievement, and heroism (Hofstede 1980). Lower score of masculinity would be closer to feminine values associated with social caring

\footnotetext{
12 This information on distance in this database is very similar to that of Wei and Subramaniyan (2007) but covers a wider range of country pairs.

${ }^{13}$ Hofstede's studies, although not without criticism, are considered to be the most widely cited studies in measurement of culture, see Kwok and Tadesse (2006) for a discussion.

${ }^{14}$ As additional robustness test, we also use similar data from Global Leadership and Organizational Behaviour Effectiveness (GLOBE) study of House et al (2004). GLOBE provides two measures of uncertainty avoidance: one related to 'values' and the other related to 'practice'. We take the uncertainty avoidance measure related to values as it is positively correlated with Hofstede's measure.
} 
and cooperation. This measure ranges from $0-100$, with higher values reflecting higher level of competitive social tendencies.

\section{Empirical Results}

We begin the discussion of empirical results by exploring average figures of all the variables. The averages are discussed on individual country basis and by grouping the countries based on level of market development. We follow the summary analysis with the discussion on various regression results.

\subsection{Summary Statistics}

The average yearly summary statistics of key variables are shown in Table II for all the 54 countries in our sample spanning a period of 2001 to $2012 .{ }^{15}$ Average foreign bias (FBIAS) towards a host country $(j)$ from all source countries $(i)$ is higher for developed markets $(-3.93)$ compared to emerging markets (-6.37). Notably, the top nine host countries with highest level of foreign bias are developed markets and nine out of the bottom ten are emerging markets. ${ }^{16}$ Unsurprisingly, the differences in average figures suggest that investors seem to prefer to invest in developed market relative to their emerging counterparts.

\section{[Insert Table II here....]}

With respect to the fundamental variables, we note significant differences between the developed and emerging markets. The yearly average real yield $(Y L D)$ for developed markets is 1.75 percent and for emerging markets is 1.24 percent. It is evident that developed markets' sovereign bonds are yielding higher real returns compared to their emerging markets'

\footnotetext{
${ }^{15}$ Data for some countries is partially missing. There are four countries (Bahrain, Kazakhstan, Mauritius and Ukraine) which will not be included in any regression as they have missing values in both economic and noneconomic categories. However, they are still reported as they are used to construct our foreign bias measure.

${ }^{16}$ The top nine countries with the highest foreign bias are (from high to low) Netherlands, United Kingdom, Germany, France, Ireland, United States, Austria, Finland, and Sweden. The bottom nine countries with the lowest foreign bias (from high to low) are Kuwait, Bahrain, Indonesia, Egypt, Israel, Thailand, Mauritius, Lebanon, and Pakistan.
} 
counterparts. This supports our conjecture that foreign investors are attracted by higher real returns. Such differences suggest a positive relation between foreign bias and real return. As expected, the exchange rate volatility $(E X C H)$ for developed markets (4.16 percent) is lower than that of emerging markets (7.57 percent). Average bond market development (BDEV) for our entire sample is 62.8 percent of GDP with developed markets (95.9 percent) showing considerably higher level of development than emerging markets (16 percent). Similarly, and as expected, developed countries have higher scores in terms of protection of property rights $(P R O P)$ and capital openness $(C A P O P)$ and they also register significantly lower country risk (CRISK).

In terms of our measures related to non-economic drivers, the common language $(C O M L A)$ average figure of 0.18 for developed markets implies that they share official language with more partner countries compared to the smaller figure of 0.14 for emerging markets. These figures are particularly driven by the proximity of European countries. With regards to trade, on average, countries in our sample conduct 4.2 percent of their overall bilateral trade $(B I L T R)$ with individual developed markets as compared to 1.3 percent with individual emerging markets. This further signifies that developed markets are economically more integrated with world markets relative to emerging markets. With respect to the source country-specific behavioural factors, though developed markets exhibit lower level of uncertainty avoidance ( UNTAV) than the emerging markets, the scores for masculinity (MASC) are similar. The figure of 59 (on a scale of 0-100) for $U N T A V^{17}$ indicates that investors from developed markets are less likely to avoid uncertain situations relative to investors from emerging markets, as reflected by the figure of 71. Apart from $M A S C$, differences between developed and emerging markets in all the variables are significant at 99 percent confidence level. The similar scores for MASC for both the markets suggest that competitiveness and

\footnotetext{
${ }^{17}$ We find similar observations using GLOBE study (House et al 2004) where developed markets have lower score for uncertainty avoidance (4.1 on a scale of 3.2 to 5.6) as compared to emerging markets (4.9).
} 
reward-seeking societal attitudes are not the exclusive preserves of either developed or emerging markets.

In summary, on average, countries with higher foreign bias are associated with higher recent return, lower exchange rate volatility, better developed markets, markets with higher level of property rights protection, more open capital markets, closer proximity with investor countries, higher share of common language and bilateral trading. In general, our summary statistics are consistent with our expectations. In the following section, we present our regression analysis on the association between foreign bias and the different measures of economic and non-economic factors.

\subsection{Regression Results}

Drawing on the theoretical framework, the general regression specification for modelling foreign bias $\left(\right.$ Fbias $\left._{i j t}\right)$ in international bond allocations is shown in equation (4):

$$
\text { Fbias }_{i j t}=\beta_{1} \text { Fund }_{j t}+\beta_{2} \text { Fam }_{i j t}+\beta_{3} \text { Behav }_{i}+\beta_{4} I N S B_{i t}+\beta_{5} \alpha_{t}+\beta_{6} \alpha_{j}+\epsilon_{i j t}
$$

where Fund $_{j t}$ is the vector of host country-specific (i.e. country $j$ ) economic fundamental variables, Fam $_{i j t}$ is a vector of bilateral familiarity variables between home and host countries, and $B e h a v_{i t}$ is a vector of the two behavioural variables specific to source country investors. Following Chan et al (2005), an additional variable, inverse of source country bias (INSB = 1 -Domestic Bias), is included to allow for the fact that a higher investment at home, i.e. source country $i$, relative to the theory would automatically lower foreign investments of investors in source countries. For instance, if a country invests $90 \%$ of its total bond holdings in domestic bonds, this obviously means that there is that lower proportion of funds available to invest abroad. Domestic bias $\left(D B_{i t}\right)$ is defined as log ratio of domestic allocations of source investors to the world benchmark as shown below in equation (5):

$$
D B_{i t}=\ln \left(w_{i t} / w_{i t}^{*}\right)
$$


where $w_{i t}$ is the domestic allocations of investors in source country $i$ which is constructed as ratio of domestic holdings to total bond holdings. Domestic allocations are computed in equation (6) as follows:

$$
w_{i t}=\frac{\text { domestic bond holdings by investors in country } i}{\text { total global bond holdings by investors in country } i}
$$

Domestic holdings by investors in country $i$ are computed as the difference between total domestic bond market outstanding values, as reported by BIS, and total bond holdings of country $i$ by foreign investors, as reflected in the data from CPIS. Total global bond holdings by investors in country $i$ is the sum of total domestic and international bond holdings by investors in country $i$. The benchmark weight $\left(w_{i t}^{*}\right)$ of country $i$ in the world market portfolio is calculated in equation (7) as follows:

$$
w_{i t}^{*}=M V_{i t} / \sum_{i=1}^{54} M V_{i t}
$$

where $w_{i t}^{*}$ is the share of country $i$ in world bond market and $M V_{i t}$ is the bond market value outstanding figure of country $i$ for the period $t$ as obtained from BIS. Finally, $\alpha_{t}$, in equation (4) are year dummies and $\alpha_{j}$ are host country dummies. Due to time-constant nature of four of our variables of interest (i.e. DIST, COMLA, UNTAV, and MASC), the use of panel (countrypair) fixed effects in a dynamic panel setting is not apporpriate. Hence, in the spirit of existing studies (Portes and Rey, 2005; Lane and Milesi-Ferretti, 2008), we include host country fixed effects. The mitigating factor is that panel-level variables that are constant over time (e.g. DIST, COMLA) will pick up some of the fixed effects for the panels (Portes and Rey, 2005). The regression results are reported with standard errors corrected at panel level clustering (i.e. country-pair level) using the White (1980) method.

Table III reports the results from different model specifications with our expected sign for the coefficients. Model I shows the estimates with only economic fundamentals and host country dummies in the regression. All fundamental factors enter the regression with expected 
signs and are significant at least at the $1 \%$ level. ${ }^{18}$ The positive regression coefficient of $Y L D$ suggests that investors are more inclined to invest in markets experiencing recent higher real return providing support to investors seeking higher returns. ${ }^{19} \mathrm{EXCH}$ with a negative coefficient reflects the expected inverse association between exchange rate volatility and foreign bias. This relation implies that international bond investors tend to avoid markets with higher exchange rate volatility, consistent with the findings of Fidora et al (2007). Similarly, from the positive sign of $B D E V$ coefficients we can infer that investors are motivated to invest more in markets with higher level of bond market development. Property rights $(P R O P)$ and capital openness $(C A P O P)$ also show statistically significant relation in the expected direction. Any remaining country-specific macroeconomic, political and financial risks (CRISK), as expected, exhibit negative association with foreign bias.

Model II presents results for foreign bias regressed against the five non-economic variables, i.e. three bilateral familiarity and two source country-specific behavioural variables, and host country dummies. All the variables bear the expected signs and are significant at the $1 \%$ level. The negative sign of DIST suggests that investors avoid markets which are further away from them geographically. Similarly, the positive coefficient associated with language indicates that common language (COMLA) with a host country is positively associated with foreign bias. For bilateral trade (BILTR), the positive coefficient reflects that higher trade conducted by a trading partner promotes foreign bias in the trading partner markets. With respect to source country-specific behavioural factors, the negative coefficient suggests that higher level of uncertainty avoidance $(U N T A V)$ leads to lower foreign bias in foreign countries,

\footnotetext{
${ }^{18}$ Although we explain the regression coefficients in its qualitative terms only, given the cross-country set-up of our investigation, the quantitative effects of the results should be interpreted with due caution.

${ }^{19}$ As an alternative measure of bond returns, we also take JP Morgan's EMBI global series for emerging markets and long-term government bond yields for developed markets from Datastream. We also adjust the bond yields of target countries by applying average exchange rate for the year from the perspective of investing countries. These alternative figures yield qualitatively similar results.
} 
which is in line with behavioural theory expectation. ${ }^{20}$ On the other hand, a higher level of masculinity $(M A S C)$ is positively associated with more foreign bias. This positive association is also in line with our expectation and supports the findings of Graham et al (2009) and Anderson et al (2011). This provides support to the notion that more competitive, assertive and reward-seeking investors have the tendency to invest more in less familiar foreign assets.

Model III considers all the economic and non-economic variables included simultaneously in the regression. The direction of association exhibited by all the variables remains essentially unchanged. Out of the eleven variables of interest, nine still exhibit statistical significance at the $1 \%$ level with the remaining two significant at $5 \%$ levels. We introduce control variables in Model IV in the form of inverse home bias of source country $(I N S B)$, and year fixed effects. INSB exhibits a statistically significant positive coefficient supporting the view that countries with lower domestic bias exhibit more foreign bias in international bond markets. Even after controlling for host country specific time-invariant variables and allowing for temporal variation in our dependent variable, the coefficients of our key explanatory variables remain qualitatively the same. The introduction of the control variables enhances the explanatory power (adjusted R-squared of 0.34) and eight out of the eleven key variables remain significant at $1 \%$ level with the other three significant at conventional levels.

The overall results in Table III suggest that, among the economic fundamentals, high real yields, better developed bond markets, higher level of capital openness and better protection of property rights of host markets attract foreign investors, while higher exchange rate volatility is a deterrent for international bond investors. As regards to non-economic factors, geographic distance acts as a natural barrier to foreign bias while common language and bilateral trade are conducive to foreign bias. Additionally, uncertainty-avoiding investors

\footnotetext{
${ }^{20}$ As noted earlier, we replace Hofstede's measure with that of GLOBE. The coefficients are similar economically and statistically. To conserve space we do not report the results but could be requested from the authors.
} 
are reluctant to diversify their bond holdings internationally and investors from more assertive and competitive societies (proxied by masculinity) tend to exhibit higher level of foreign bias, even after controlling for economic fundamentals. To account for the possible persistence of FBIAS across country-pairs, we use a dynamic panel model in the spirit of Arellano and Bond (1991) using one-year lag of FBIAS as an additional dependent variable and assuming all other variables to be exogenous. All time-constant variables drop out of the analysis but the remaining variables have their expected signs and all are significant at conventional levels (results available on request).

\section{[Insert Table III here....]}

\subsection{Horse Race between Economic and Non-Economic Factors}

We examine the relative importance between economic and non-economic factors using three different metrics. First, we compare the adjusted R-squared of the regressions that include economic and non-economic variables, followed by variance decomposition analysis, and then using standardized beta figures. Results in Table III show that the R-squared of non-economic variables is 0.28 compared to 0.08 for economic fundamentals (Model I and II). ${ }^{21}$ This provides a strong indication towards the higher explanatory power inherent in the non-economic variables, as compared to economic fundamentals, in explaining the variance in foreign bias.

To further examine the relative importance of each of the variables, we perform variance decomposition analysis following Bekaert and Wang (2009). We produce fitted values $\left(F B_{i, j, t}\right)$ of foreign bias from Model III (of Table III excluding country dummies) and calculate relative explanatory power (VARD) for each of the explanatory variables $(X)$ using equation (8) below:

$$
\operatorname{VARD}_{(X)}=\beta_{(X)} \frac{\operatorname{cov}\left(F B_{i, j, t}, X_{i / j, t}\right)}{\operatorname{var}\left(F B_{i, j, t}\right)}
$$

\footnotetext{
${ }^{21}$ Exclusion of host country dummies yields an adjusted R-square of 0.21 for familiarity and 0.3 for fundamentals.
} 
where $\operatorname{VARD_{(X)}}$ is the relative explanatory power of explanatory variable $X ; \beta_{(X)}$ is the beta coefficient for variable $X$ as obtained from our regression (Model III); $\operatorname{cov}\left(F B_{i, j, t}, X_{i / j, t}\right)$ is the covariance between the fitted values $\left(F B_{i, j, t}\right)$ and variable $X$. Finally, var $\left(F I B_{i, j, t}\right)$ reflects the variance of the fitted values $\left(F B_{i, j, t}\right)$. From the above model, VARD for a given explanatory variable can be either negative or positive. The sign can be different from beta coefficient of the given variable because $V A R D$ measures unconditional variance contribution while beta coefficient in the regression measures partial correlation (Bekaert and Wang 2009).

Table III shows that distance (DIST) and uncertainty avoidance (UNTAV) exhibit VARD measures of $55 \%$ and $28 \%$ respectively suggesting that more than three quarters of unconditional variance of foreign bias is explained by these two variables combined (total of VARD measures add up to unity by construction). Other variables, in the order of importance, are $B D E V, E X C H$, and $M A S C$ carrying $V A R D$ measures of $7.3,2.7$, and 2.3 percent respectively. Finally, and for further comparison, we also present the standardized regression coefficients $^{22}$ for the independent variables in the final column of Table III. DIST and UNTAV still register the biggest impact on foreign bias with a change of one standard deviation in each of these two variables corresponding to reduced foreign bias by 37 and 26 percent respectively. In summary, our data provides consistent evidence towards the notion that non-economic factors, particularly related to DIST and UNTAV, explain more of foreign bias than economic fundamentals.

\subsection{Endogeneity}

\footnotetext{
${ }^{22}$ All independent variables are rescaled to have a standard deviation of one and we regress the dependent variable against the standardized variables.
} 
Errunza (2001) notes that higher level of foreign investment can lead to reforms in local capital markets. This could arguably cause some of the explanatory variables that we have used, particularly bond market development $(B D E V)$, capital openness $(C A P O P)$ and property rights measures $(P R O P)$, to be endogenous in our regression models. ${ }^{23}$ Since bond yield $(Y L D)$ in our analysis is the average for the preceding 12 months and exchange rate volatility $(E X C H)$ is the moving average over preceding 36 months, the issue of endogeneity is mitigated for these two variables. To address concerns of endogeneity for the remaining variables, we repeat all the variants of our basic regression model using one-year lag of the endogenous variables. Table IV shows that the coefficients observed after using one-year-lagged values of endogenous variables remain qualitatively similar to our earlier results in Table III. As an additional test, we use factor analysis to replace all fundamental economic variables with a single factor $(\text { FactorFund })^{24}$ and use a one-year lag of this first component factor in our regression models. FactorFund is still significant (results available on request) indicating that our results do not suffer significantly from reverse causality.

\section{[Insert Table IV here....]}

\subsection{Financial Centres}

We consider the possibility that institutional investors incorporated in financial centres could be investing on behalf of investors of many different countries. For instance, it is possible that institutional investors can be incorporated within certain jurisdiction, for instance purely for tax purposes, and investors from other countries could be investing in foreign bonds through such institutional investors. This creates a problem in our data by obscuring the actual source country of such foreign bond investments. To address this issue, we discard all investments originating from countries considered to be financial centres and re-run our four models in

\footnotetext{
${ }^{23}$ This is less of a problem for familiarity variables as all of them, apart from bilateral trade, are constant over time.

${ }^{24}$ The relevant Kaiser-Meyer-Olkin (KMO) measure is 0.69 , which justifies the use of this component.
} 
Table III. Following Chan et al (2005), we consider United States, United Kingdom, Switzerland, Ireland, Japan, Hong Kong and Singapore as financial centres. Results presented in Table V show that the overall results remain essentially the same.

\section{[Insert Table V here....]}

\subsection{Effect of the Two Crises Periods}

Empirical evidence suggests that foreign investors avoid markets during crisis periods and especially countries where they do not get information transparently (Gelos and Wei 2005) and that outside investors tend to exhibit herding behaviour during crises (Kim and Wei 2002). Investors often rebalance their portfolio during times of economic distress (known as 'flightto-safety' and/or 'flight-to-liquidity') (Beber et al 2009). Intuitively, foreign bias can be expected to decrease during such crises as the investment environment is extremely uncertain. We segregate the time periods in our sample into two distinct periods: crisis and non-crisis (normal). Crisis years for our purpose include five years spanning the global financial crisis (2007-09) and Eurozone debt crisis (2009-11) and the remaining years are treated as normal times. We choose 2007 as the start of the global financial crisis in line with chronology of global financial crisis provided by Federal Reserve Bank of St. Louis. ${ }^{25}$ Our choice of 2009 as the start of Eurozone debt crisis is motivated by the fact that the global financial crisis had already peaked and had started to be transformed into sovereign debt crisis in the Eurozone countries by mid-2009 (Afonso et al 2015).

We conduct a simple mean difference paired t-test to evaluate any marked changes in foreign bias during these two different time periods. The results are presented in Table VI. A significant reduction in foreign bias measure is apparent during the crises years when foreign bias measure decreased from -4.867 to -5.289 (Panel A). In a comparison of the foreign bias

\footnotetext{
25 See https://www.stlouisfed.org/financial-crisis/full-timeline. A number of other studies (including Grammatikos and Vermeulen 2012; Kalemli-Ozcan et al 2013) also take the year 2007 as the start of the global financial crisis.
} 
figures for normal times with each crisis period, we find that foreign bias measure did not decrease at all during the global financial crisis (Panel B). In fact, there has been a slight increase in foreign bias during 2007-08, though the difference is not statistically significant. However, the period of Eurozone debt crisis witnessed a marked decline in foreign bias measure, which is significant (Panel C). A plausible explanation is that as the global financial crisis mainly impacted financial institutions, its impact on international bonds was subdued because of the relative safety of bonds (most of which are sovereign). However, the Eurozone debt crisis was an economically turbulent period with respect to uncertainty in bond investments.

We develop this further, by comparing the foreign bias figures for the five GIIPS countries that were most severely affected by the Eurozone crisis. The results reported in Panel D, which are statistically significant, show that the foreign bias measure decreases by a greater extent in these countries. As a result, our preliminary analysis suggests that investors lower their foreign bond bias during international debt crises, especially in the most affected countries. However, given the global systematic and different nature of crisis, such divestment in bonds is not apparent during the global financial crisis. We conjecture that the prevalence of crisis in a host country serves to increase the marginal deadweight costs associated with investing in that country leading to under-weighting of the crisis countries by a greater extent.

\section{[Insert Table VI here....]}

To ensure robustness of these findings, we use regression analysis to re-examine the possible changes in foreign bias during normal times and also during the two crises. For Eurozone debt crisis, we create a crisis year dummy (ECrisis) (equalling 1) for the years 2009 - 2011. Similarly for global financial crisis, we create crisis dummy GCrisis (equalling 1) for years 2007-08 and run a regression with the following specification in equation (9): 


$$
\begin{aligned}
\text { Fbias }_{i j t}= & \beta_{1} \text { GCrisis }+\beta_{2} \text { ECrisis }+\beta_{3} \text { Fund }_{j t}+\beta_{4} \text { Fam }_{i j t}+\beta_{5} \text { Behav }_{i} \\
& +\beta_{6} \text { INDHB }_{i t}+\beta_{7} \alpha_{j}+\epsilon_{i j t}
\end{aligned}
$$

We present the results in Table VII (Model I). Confirming our earlier findings that foreign bias decreased significantly during the Eurozone debt crisis, ECrisis bears a negative sign and is statistically significant at $1 \%$ level but GCrisis shows no significant impact.

In Model II, we add two more dummy variables to equation (9): EZone is a dummy variable of 1 for all Eurozone member countries (and zero otherwise) and $E u Z C r$ is a dummy variable of 1 for Eurozone member countries during Eurozone crisis years only. EZone has a positive and significant coefficient implying that Eurozone member countries, on average, have received higher foreign bias than other countries during normal times. However, the $\mathrm{EuZCr}$ is insignificant implying that foreign bias did not decrease significantly in Eurozone countries as a whole during 2009-11; this is possibly because in our sample Eurozone is heavily weighted by Germany and France whose bond markets have fared relatively better during Eurozone debt crisis. If we exclude Germany and France, the $\mathrm{EuZCr}$ coefficient, as reported in Model III, is significant (with negative sign) suggesting that foreign bias in most of the Eurozone members decreased during the 2009-11 Eurozone debt crisis.

In Model IV, we introduce a dummy variable GIIPS (equalling 1 for GIIPS countries) to replace EZone. Similarly, we replace EuZCr with GIIPSCr which is a dummy for GIIPS countries during Eurozone crisis years only. GIIPSCr is negative as expected supporting our earlier finding that foreign bias further decreased in GIIPS countries during Eurozone debt crisis even after allowing for the general decline in foreign bias during 2009-11. GIIPS does not exhibit significant coefficient implying that these countries did not command any higher preference over non-Eurozone members even during normal times (unlike other Eurozone countries). To ensure robustness of this finding and to further explore if the impact on FBIAS is influenced by regional effects, we segregate our data between EMU and non-EMU (i.e. rest 
of the world) source markets; and EMU and non-EMU host markets, and re-run this test. The results are presented in Appendix 3 to 6. We do find evidence of Euro bias (Balli et al., 2010) where EMU countries tend to invest more in fellow EMU countries. ${ }^{26}$ Nevertheless, the results in these appendices provide consistent evidence that FBIAS decreased during the Eurozone crisis (but not during the global financial crisis); and this decrease was severe for the host countries that were most affected by the debt crisis.

\section{[Insert Table VII here....]}

Overall, the results in Table VII provide strong evidence that foreign bias decreased significantly during Eurozone debt crisis and that the magnitude of reduction was greater in those countries that were most severely affected by the crisis.

We examine further whether this change in foreign bond bias during Eurozone debt crisis was influenced more by economic fundamentals or by non-economic factors. We extract the first component of the six economic fundamentals using factor analysis and name it FactorFund. ${ }^{27}$ Similarly we extract first component of the non-economic factors and name it FactorFam. To assess whether the importance of variables change during crises, we follow the approach in Gelos and Wei (2005). We interact each of the factor components FactorFund and FactorFam with Eurozone debt crisis dummy (ECrisis) to create interaction terms CrFundW (FactorFund * ECrisis) and CrFamW (FactorFam * ECrisis) and run the regression using equation (10) as shown below:

$$
\begin{gathered}
\text { Fbias }_{i j t}=\beta_{1} \text { CrFundW }_{j t}+\beta_{2} \text { CrFamW }_{i j t}+\beta_{3} \text { FactorFund }_{j t}+\beta_{4} \text { FactorFam }_{i j t} \\
+\beta_{5} \text { INSB }_{i t}+\beta_{6} \alpha_{j}+\epsilon_{j t}
\end{gathered}
$$

\footnotetext{
${ }^{26}$ We thank the anonymous referee for this suggestion.

${ }^{27}$ CRISK enters factor analysis in absolute values rather than the residuals.
} 
In Table VIII Model I, FactorFund enters the regression with positive sign that is significant at the $1 \%$ level. It is important to note the factor loadings ${ }^{28}$ which show that $B D E V$ and PROP carry the highest positive values and $E X C H$ and $C R I S K$ carry significant negative values. As such, positive value for FactorFund implies more foreign bias towards countries with lower $C R I S K$, lower $E X C H$, higher $P R O P$ and higher $B D E V$ which is consistent with our earlier findings. FactorFam is negative and statistically significant at the $1 \%$ level. In the factor loadings for FactorFam, ${ }^{29}$ DIST and UNTAV have the two highest positive values while COMLA and BITRD have negative values. This suggests that the negative sign of FactorFam implies more foreign bias towards countries with common language, more trade, less distance, and from investors who have lower level of UNTAV. This is also consistent with our earlier findings. However, the key variable of interest in Model I is CrFamW which has the same negative sign as FactorFam implying that the importance of non-economic variables gained further importance during Eurozone crisis. No such inference can be made for economic fundamentals as CrFundW, despite bearing the same sign as FactorFund, is not significant.

In Model II, we focus mainly on Eurozone member countries to assess possible changes in the importance of fundamentals and familiarity variables. We replace $C r F u n d W$ and $C r F a m W$ by $C r F u n d E u$ and $C r F a m E u$ respectively. $C r F u n d E u$ is an interaction term involving FactorFund, ECrisis, and EZone and CrFamEu involves interacting FactorFam, ECrisis, and EZone. The variable of interest $\mathrm{CrFamEu}$ is negative implying enhancement of importance of non-economic variables during the crisis. Interestingly, the coefficient of $\mathrm{CrFamEu}(-1.06)$ remains similar to that of $C r F u n d W$ in Model I. This is explained by the influence of France and Germany, without which the $C r F a m E u$ would be further negative.

\footnotetext{
${ }^{28}$ Factor loadings (unrotated) for FactorFund are: YLD (-0.21), EXCH (-0.58), BDEV (+0.71), PROP (+0.79), CAPOP (+0.52), CRISK (-0.8).

${ }^{29}$ Factor loadings (unrotated) for FactorFam are: DIST (+0.41), COMLA (-0.30), BITRD (-0.39), UNTAV $(+0.28)$, and MASC (+0.15).
} 
In Model III, we focus on the GIIPS countries. Accordingly, we replace CrFundEu and CrFamEu by CrFund5 and CrFam5 respectively. CrFund5 is an interaction term of FactorFund, ECrisis, and GIIPS and CrFam5 involves interacting FactorFam, ECrisis, and GIIPS. CrFam5 is negative at the $1 \%$ level (similar to FactorFam) and its coefficient is markedly more negative to the comparable interaction terms in the first two models. This implies that the importance of non-economic factors get even more pronounced when it comes to investing in crisis-affected countries. ${ }^{30}$

Overall, results in Table VIII suggest that though economic fundamentals and noneconomic factors are both important in bond investment during normal times, the importance of non-economic factors become much stronger and pronounced during debt crisis, and especially so when investing in crisis affected countries. A plausible explanation is that as debt crisis unfolds, bond investors would be more inclined to withdraw from those affected markets, and particularly from distant and unfamiliar markets, regardless of economic fundamentals.

\section{[Insert Table VIII here....]}

\subsection{Developed Versus Emerging Markets}

So far we have conducted our analyses in a global setting without distinguishing between emerging and developed markets. However, our summary statistics in Section 4.1 show that there are considerable differences between the macroeconomic fundamentals of developed and emerging markets. On the behavioural front, though the average MASC is similar for both sets of countries, the level of $U N T A V$ is lower for developed markets. This motivates us to conduct further tests to unravel any different investment patterns that could be observed among

\footnotetext{
${ }^{30} \mathrm{We}$ also interact each of the key variables separately (with crisis year dummy ) to create 11 interaction terms on top of the explanatory variables in our regression analysis. VIF score for some of the interaction terms shoot up to more than 10 resulting in some of the variables of interest showing up as statistically non-significant due to severe multicollinearity. Despite this, DIST and UNTAV continue to exhibit increased impact during the crisis. Results are available from authors on request.
} 
developed and emerging countries. ${ }^{31}$ To achieve this, we re-run equation (4) separately for host emerging markets and host developed markets, and calculate the VARD measures and standardized beta for the variables of interest. The results shown in Appendix 1 show qualitatively similar results (to Table III) suggesting that the impact of variables of interest are pervasive across emerging as well as developed markets. We further extend this analysis to examine investments across various permutations of emerging and developed markets; specifically, we examine investments: i) from emerging markets only; ii) from developed markets only; iii) from emerging to developed markets; iv) from developed to developed markets; v) from emerging to emerging markets; and vi) from developed to emerging markets. For brevity, we show these results in Appendix 2 without VARD measures and standardized beta coefficients but again, the results are qualitatively similar.

\section{Conclusions}

In this study we investigate three important issues related to foreign bond investments. First, we examine whether economic fundamentals and/or non-economic factors are associated with cross-country biases, including how investor-specific behavioural features are related to foreign allocation in bonds. Second, using the 2007-09 global financial and 2009-11 European sovereign debt crisis as an experiment, we also investigate whether investors reallocate/rebalance their portfolio during these turbulent economic periods. Finally, we also examine whether the crisis periods interact with factors driving biases in international bond allocations.

Using country level data from 54 countries over 12 years, we find that economic fundamentals and non-economic factors including familiarity and behavioural factors are both important drivers of foreign bias, but bond foreign bias is influenced more by non-economic

\footnotetext{
${ }^{31}$ We thank the anonymous referee for this suggestion.
} 
factors than economic fundamentals. We find geographical distance between countries and the uncertainty avoidance attitudes of investors to be more influential drivers of foreign bias compared to economic fundamentals. These results are robust using various tests including addressing endogeneity and exclusion of the main financial centres.

We find that the deadweight costs of investing in bonds of countries experiencing debt crisis increase, which in turn lower foreign bias (i.e. lower allocation with respect to benchmark) in such affected countries. Our analysis of Eurozone debt crisis further indicates that such under-weighting of crisis countries is predominantly driven by the non-economic factors during turbulent economic periods. However, when faced with financial/banking crisis (i.e. global financial crisis), we do not find evidence of change in the patterns of foreign bond bias. The findings of the study suggest that government policies aimed at increasing information on domestic markets to foreign investors should attract higher foreign investments, as implied by the impact of familiarity and behavioural factors, particularly during volatile economic periods. 


\section{References}

Afonso, A., Arghyou, M., \& Kontonikas, A. (2015). The determinants of sovereign bond yield spreads in the EMU. ECB Working Paper Series 1781.

Ahearne, A., Griever, W., \& Warnock, F. (2004). Information costs and home bias: An analysis of US holdings of foreign equities. Journal of International Economics, 62, 313-336.

Anderson, C., Fedinia, M., Hirschey, M., \& Skiba, H. (2011). Cultural influences on home bias and international diversification by institutional investors. Journal of Banking and Finance, 35(4), 916-934.

Arellano, M., Bond, S., 1991. Some tests of specification for panel data: Monte Carlo evidence and an application to employment equations. The Review of Economic Studies, 58, 277.

Bae, K., Yun, Y., \& Bailey, W. (2006). Determinants of bond holdings by foreign investors. BIS papers no. 30.

Balli, F., Basher, S.A., Ozer-Balli, H. (2010). From home bias to Euro bias: Disentangling the effects of monetary union on the European financial markets. Journal of Economics and Business, 62, 347-366

Beber, A., Brandt, M., \& Kavajecz, K. (2009). Flight-to-quality or flight-to-liquidity? Evidence from the Euroarea bond market. The Review of Financial Studies, 22(3), 925-957.

Bekaert, G., \& Wang, X. (2009). Home Bias Revisited, SSRN Working Paper. Retrieved from http://ssrn.com/abstract $=1344880$

Bekaert, G., Harvey, C., Lundblad, C., \& Siegel, S. (2014). Political risk spreads. Journal of International Business Studies, 45, 471-493.

Beugelsdijk, S., \& Frijns, B. (2010). A cultural explanation of the foreign bias in international asset allocation. Journal of Banking and Finance, 34(9), 2121-2133.

Burger, J., \& Warnock, F. (2003). Diversification, original sin, and international bond portfolios. Retrieved from International Finance Discussion Paper No.755: http://dx.doi.org/10.2139/ssrn.381861

Campbell, J., \& Taksler, G. (2003). Equity volatility and corporate bond yields. The Journal of Finance, 58(6), 2321-2349.

Chan, K., Covrig, V., \& Ng, L. (2005). What determines the domestic and foreign bias? Evidence from mutual fund equity allocations worldwide. The Journal of Finance, 60(3), 1495-1534.

Chui, A., Kwok, C., (2008). National culture and life insurance consumption. Journal of International Business Studies, 39, 88-101.

Cihak, M., Demirguc-Kunt, A., Feyen, E., \& Ross, L. (2013). Financial development in 205 economies, 1960 to 2010. Journal of Financial Perspectives, EY Global FS Institute, 1(2), 17-36.

Cooper, I., \& Kaplanis, E. (1986). Costs to crossborder investment and international equity market equilibrium. In J. Edwards, J. Franks, C. Mayer, \& S. Schaefer (Eds.), Recent Developments in Corporate Finance (pp. 209-240). New York: Cambridge University Press.

Cooper, I., \& Kaplanis, E. (1994). Home bias in equity portfolios, inflation hedging, and international capital market equilibrium. Review of Financial Studies, 7(1), 45-60.

Cooper, I., Sercu, P. \& Vanpee, R. (2012). The equity home bias puzzle: a survey. In G. Constantinides, ed. Foundations and Trends in Finance. Hanover, Ma: now Publishers Inc. pp.289-416.

Cruces, J., \& Trebesch, C. (2013). Sovereign defaults: the price of haircuts. American Economic Journal: Macroeconomics, 5(3), 85-117.

Curcuru, S., Thomas, C., Warnock, F., \& Wongswan, J. (2011). US international equity investment and past and prospective returns. American Economic Review, 101(7), 3440-3455.

Cuypers, I., Ertug, G., \& Jennart, J. (2015). The effects of linguistic distance and lingua franca proficiency on the stake taken by acquirers in cross-border acquisitions. Journal of International Business Studies, 46, 429442.

De Moor, L., Vanpée, R. (2013). What drives international equity and bond holdings? An empirical study. Applied Financial Economics 23, 1067-1082.

Eichengreen, B., \& Mody, A. (2000). What explains changing spreads on emerging market debt? In S. Edwards (Ed.), Capital Flows and the Emerging Economies: Theory, Evidence and Controversies (pp. 107-134). Chicago: University of Chicago Press.

Elton, E. (1999). Expected return, realized return, and asset pricing tests. The Journal of Finance, 54(4), 11991220.

Errunza, V. (2001). Foreign portfolio equity investments, financial liberalization, and economic development. Review of International Economics, 9, 703-726.

Fidora, M., Fratzscher, M., \& Thimann, C. (2007). Home bias in global bond and equity markets: the role of real exchange rate volatility. Journal of International Money and Finance, 26(4), 631-655.

Forbes, K. (2010). Why do foreigners invest in the United States? Journal of International Economics, 80, 3-21.

Gelos, R., \& Wei, S. (2005). Transparency and international portfolio holdings. Journal of Finance, 60(6), 29873020 .

Gleditsch, K. (Online). Retrieved 05 15, 2014, from http://privatewww.essex.ac.uk/ ksg/statelist.html 
Graham, J., Harvey, C., \& Huang, H. (2009). Investor competence, trading frequency, and home bias. Management Science, 55(7), 1094-1106.

Grammatikos, T., \& Vermeulen, R. (2012). Transmission of the financial and sovereign debt crises to the EMU: Stock prices, CDS spreads and exchange rates. Journal of International Money and Finance, 31(3), 517533.

Grinblatt, M., \& Keloharju, M. (2001). How distance, language, and culture influence stockholdings a trades. Journal of Finance, 56, 1053-1073.

Gwartney, J., Lawson, R., \& Hall, J. (2014). Economic Freedom of the World: 2014 Annual Report. Fraser Institute.

Heath, C., \& Tversky, A. (1991). Preferences and beliefs: ambiguity and competence in choice under uncertainty. Journal of Risk and Uncertainty, 4, 5-28.

Hofstede, G. (1980). Culture's Consequences: International Differences in Work-related Values (2nd ed.). Beverly Hills, California: Sage Publications.

House, R., Hanges, P., Javidan, M., Dorfman, P., \& Gupta, V. (2004). Culture, Leadership, and Organizations: The GLOBE Study of 62 Societies. Thousand Oaks, CA: Sage.

Huberman, G. (2001). Familiarity breeds investment. Review of Financial Studies, 14(3), 659-680.

Kalemli-Ozcan, S., Papaioannou, E., \& Perri, F. (2013). Global banks and crisis transmission. Journal of International Economics, 89(2), 495-510.

Kaplanski, G., Levy, H., Veld, C., Veld-Merkoulova, Y., (2015). Do happy people make optimistic investors? Journal of Financial and Quantitative Analysis, 50, 145-168.

Kim, W., \& Wei, S. (2002). Foreign portfolio investors before and during a crisis. Journal of International Economics, 56, 77-96.

Kirkman, B.L., Lowe, K.B., Gibson, C., (2006). A quarter century of Culture's Consequences: A review of empirical research incorporating Hofstede's cultural values framework. Journal of International Business Studies 37, 285-320

Kwok, C., \& Tadesse, S. (2006). National culture and financial systems. Journal of International Business Studies, $37,227-247$.

La Porta, R., Lopez-De-Silanes, F., Shleifer, A., \& Vishny, R. (1997). Legal determinants of external finance. Journal of Finance, 52(3), 1131-1150.

Lane, P., \& Milesi-Ferretti, G. (2008). International investment patterns. Review of Economics and Statistics, 90(3), 538-549.

Lau, S., Ng, L., \& Zhang, B. (2010). The world price of home bias. Journal of Financial Economics, 97, 191-217.

Malmendier, U., \& Nagel, S. (2011). Depression babies: do macroeconomic experiences affect risk taking? The Quarterly Journal of Economics, 126(1), 373-416.

McKinsey and Company. (2011). Retrieved October 25, 2014, from http://www.mckinsey.com/insights/global_capital_markets/mapping_global_capital_markets_2011

McLeavy, D., \& Solnik, B. (2014). Global Investments (6th ed.). Pearson.

Portes, R., Rey, H., (2005). The determinants of cross-border equity flows. Journal of International Economics, 65, 269-296.

Wei, S., \& Subramaniyan, A. (2007). The WTO promotes trade, strongly but unevenly. Journal of International Economics, 72(1), 151-175.

White, H. (1980). A heteroskedasticity-consistent covariance matrix estimator and a direct test for heteroskedasticity. Econometrica 48, 817-839. 
Table I: Key Variables and Definitions

\begin{tabular}{|c|c|c|}
\hline $\begin{array}{l}\text { Variable } \\
\text { name }\end{array}$ & Measure & Definition \\
\hline FBIAS & Foreign Bias & $\begin{array}{l}\log \text { (ratio of weight of allocation made by foreigners to host country's } \\
\text { market weight in world bond market) }\end{array}$ \\
\hline$Y L D$ & Real yield on bonds & $\begin{array}{l}\text { annual yield on } 10 \text {-year government bonds minus inflation minus } \\
\text { sovereign risk; annual yield sourced from International Financial } \\
\text { Statistics (\%) and Economic Intelligence Unit; consumer price } \\
\text { inflation is from WDI; sovereign risk measure based on Moody's } \\
\text { ratings is from Damodaran Online. Alternative figures on long-term } \\
\text { bond yields are taken from JP Morgan EMBI Global series (for } \\
\text { developing markets) and 10-year sovereign bonds from Datastream } \\
\text { (for developed markets). }\end{array}$ \\
\hline$E X C H$ & Exchange rate volatility & $\begin{array}{l}\text { yearly volatility in indices for effective exchange rate; volatility for } \\
\text { preceding } 36 \text { months from year-end is taken ; raw data is from BIS. }\end{array}$ \\
\hline$B D E V$ & Bond market development & $\begin{array}{l}\log \text { ratio of private debt (both domestic and international) to GDP; data } \\
\text { sourced from Global Financial Development Database available at: } \\
\text { http://data.worldbank.org/data-catalog/global-financial-development. }\end{array}$ \\
\hline
\end{tabular}

PROP Protection of property rights

sourced from table 2c of Economic Freedom of the World 2013 dataset; is within the scale of 1 to 10 and higher measure indicates clearer definition and higher protection of property rights.

CAPOP Capital openness (capital control)

CRISK Country risk

UNTAV Uncertainty avoidance; reflects the extent to which members of a society feel uncomfortable with uncertainty and ambiguity.

MASC Masculinity; represents a preference in society for achievement, heroism, assertiveness and material rewards for success.

DIST Log of distance in Kilometres between capital cities

COMLA Common language

BILTR Bilateral trade weight assigned by partner countries

INSB Control for foreign bond allocation of home country's investors

ECrisis Dummy for Eurozone debt crisis

equal to 1 for years 2009-2011; otherwise 0 .

GIIPS Dummy for countries most severely affected by Eurozone debt crisis

GCrisis Dummy for global financial crisis

taken from table 4Dii of Economic Freedom Dataset 2013; within a scale of 0 to 10; higher measure indicates lower level of restrictions on investment and foreign ownership in that country.

Moody's country ratings; higher score indicates higher risk.

Hofstede's measure of uncertainty avoidance (Hofstede 1980); alternative measure is from GLOBE study's (House et al 2004).

Hofstede's measure of masculinity (Hofstede 1980).

http://privatewww.essex.ac.uk/ ksg/statelist.html.

dummy variable of 1 if a country pair share a language; data from Wei and Subramanian (2007) sourced from http://users.nber.org/ wei/data.html which is derived from CIA Factbook.

from IMF Direction of Trade Statistics (DOTS), it is the portion of total trade (imports and exports) conducted, from the perspective of source country, with a host country.

(1- domestic bias) of home country (country $i$ ).

equal to 1 for Greece, Ireland, Italy, Portugal, and Spain; otherwise 0.

equal to 1 for years 2007-2008; otherwise 0 . 
Table II

Summary Statistics of Key Variables

FBIAS is a measure of bond foreign bias at country level. Foreign bias reflects deviation of country $j$ 's share in bond holdings for each source country $i(i \neq j)\left(w_{\mathrm{ij}}\right)$ from the world bond market capitalization weight of country $\mathrm{j}\left(w^{*} \mathrm{j}\right)$. We calculate foreign bias by $\log \left(\mathrm{w}_{\mathrm{ij}} / w^{*} \mathrm{j}\right)$. This table presents overall average of foreign bias measure taking yearly average of source countries' bias in country $j$ for each given year. Remaining variables include i) Economic Fundamentals for host country $j$ and ii) bilateral and investor-specific Familiarity Factors. Economic Fundamentals include annual yield on long-term government bonds $(Y L D)$, exchange rate volatility $(\mathrm{EXCH})$, bond market development $(B D E V)$, protection of property rights $(P R O P)$, capital openness $(C A P O P)$, and country risk (CRISK). Familiarity Factors include distance (in kilometers) between countries (DIST), common language (COMLA) dummy, average bilateral trade weight assigned by partner countries (BILTR), uncertainty avoidance (UNTAV) of source country, and masculinity (MASC) of source country. All variables are sourced as reported in Table 1 . Data is for years 2001 to 2012.

Panel A: All Countries

\begin{tabular}{|c|c|c|c|c|c|c|c|c|c|c|c|c|}
\hline Country & FBIAS & YLD (\%) & $\mathrm{EXCH}(\%)$ & $\begin{array}{r}\text { BDEV } \\
(\% \text { GDP })\end{array}$ & $\begin{array}{l}\text { PROP } \\
(0-10)\end{array}$ & $\begin{array}{r}\text { CAPOP } \\
(0-10)\end{array}$ & $\begin{array}{r}\text { CRISK } \\
(0-10)\end{array}$ & $\begin{array}{r}\text { DIST } \\
(\mathrm{km})\end{array}$ & $\begin{array}{l}\text { COMLA } \\
\text { (average) }\end{array}$ & $\begin{array}{r}\text { BILTR } \\
(\%)\end{array}$ & $\begin{array}{r}\text { UNTAV } \\
(1-100)\end{array}$ & $\begin{array}{c}\text { MASC } \\
(1-100)\end{array}$ \\
\hline Argentina & -5.53 & 14.60 & 10.52 & 8.4 & 2.98 & 1.98 & 6.55 & 11,379 & 0.11 & 1.03 & 86 & 56 \\
\hline Australia & -3.82 & 2.48 & 8.19 & 95.1 & 8.18 & 2.57 & 0.05 & 13,277 & 0.37 & 2.19 & 51 & 61 \\
\hline Austria & -2.80 & 1.77 & 1.94 & 97.2 & 8.42 & 4.16 & 0.00 & 4,365 & 0.03 & 1.56 & 70 & 79 \\
\hline Bahrain & -7.27 & $\mathrm{n} / \mathrm{a}$ & $\mathrm{n} / \mathrm{a}$ & 21.8 & 7.33 & 6.79 & 1.30 & 5,670 & 0.06 & 0.11 & $\mathrm{n} / \mathrm{a}$ & $\mathrm{n} / \mathrm{a}$ \\
\hline Belgium & -3.91 & 1.41 & 2.37 & 104.2 & 7.60 & 5.86 & 0.48 & 4,352 & 0.17 & 3.46 & 94 & 54 \\
\hline Brazil & -5.02 & 4.46 & 12.48 & 21.8 & 5.40 & 3.78 & 3.17 & 10,075 & 0.03 & 2.37 & 76 & 49 \\
\hline Bulgaria & -5.44 & -0.04 & 3.35 & 1.9 & 3.70 & 6.10 & 2.76 & 3,998 & 0.00 & 0.50 & 85 & 40 \\
\hline Canada & -4.41 & 2.30 & 5.93 & 54.4 & 8.23 & 7.39 & 0.05 & 8,176 & 0.41 & 1.75 & 48 & 52 \\
\hline Chile & -5.76 & 2.67 & 7.59 & 21.4 & 6.49 & 5.58 & 0.83 & 11,778 & 0.10 & 0.77 & 86 & 28 \\
\hline Colombia & -7.15 & 3.40 & 9.05 & 1.8 & 4.86 & 1.13 & 1.82 & 9,598 & 0.10 & 0.28 & 80 & 64 \\
\hline Czech Republic & -5.33 & 0.57 & 6.16 & 15.6 & $\mathrm{n} / \mathrm{a}$ & $\mathrm{n} / \mathrm{a}$ & 0.90 & 3,816 & 0.00 & 1.21 & 74 & 57 \\
\hline Denmark & -4.45 & 1.66 & 2.43 & 188.7 & 8.53 & 7.92 & 0.00 & 4,425 & 0.33 & 1.24 & 23 & 16 \\
\hline Egypt & -7.60 & 0.26 & $\mathrm{n} / \mathrm{a}$ & 1.2 & 5.00 & 5.16 & 2.76 & 5,053 & 0.41 & 0.54 & 80 & 45 \\
\hline Estonia & -7.45 & 3.52 & 2.63 & 2.2 & 7.18 & 6.60 & 0.96 & 4,059 & 0.00 & 0.38 & 60 & 30 \\
\hline Finland & -3.43 & 1.97 & 2.88 & 45.7 & 8.87 & 4.94 & 0.00 & 4,603 & 0.03 & 1.24 & 59 & 26 \\
\hline France & -2.55 & 2.11 & 2.51 & 102.0 & 8.06 & 6.44 & 0.02 & 4,893 & 0.10 & 6.53 & 86 & 43 \\
\hline Germany & -2.08 & 1.92 & 3.23 & 107.2 & 8.62 & 5.27 & 0.00 & 4,854 & 0.07 & 13.66 & 65 & 66 \\
\hline Greece & -4.14 & 2.65 & 4.34 & 48.1 & 5.86 & 4.89 & 2.54 & 4,616 & 0.00 & 0.62 & 100 & 57 \\
\hline Hong Kong & -6.24 & 0.86 & 4.48 & 39.5 & 8.21 & 7.87 & 0.59 & 8,458 & 0.36 & 2.06 & 29 & 57 \\
\hline Hungary & -4.58 & 1.40 & 7.49 & 11.5 & 5.79 & 5.05 & 1.44 & 3,962 & 0.00 & 1.14 & 82 & 88 \\
\hline India & -6.45 & -3.86 & 5.63 & 3.3 & 6.12 & 0.00 & 2.64 & 6,686 & 0.36 & 3.13 & 40 & 56 \\
\hline Indonesia & -7.53 & 0.87 & 10.17 & 4.7 & 4.50 & 1.41 & 4.18 & 9,623 & 0.00 & 1.54 & 48 & 46 \\
\hline Ireland & -2.66 & 3.09 & 3.73 & 258.3 & 8.34 & 8.36 & 0.81 & 4,921 & 0.33 & 0.92 & 35 & 68 \\
\hline Israel & -8.68 & -0.40 & 5.40 & 6.5 & 6.89 & 7.83 & 0.93 & 5,196 & 0.30 & 0.50 & 81 & 47 \\
\hline Italy & -3.81 & 1.70 & 2.55 & 72.7 & 5.81 & 7.63 & 0.73 & 4,767 & 0.00 & 6.07 & 75 & 70 \\
\hline Japan & -7.35 & 0.67 & 7.84 & 47.7 & 7.70 & 5.51 & 0.80 & 9,285 & 0.00 & 6.59 & 92 & 95 \\
\hline Kazakhstan & -5.15 & -2.74 & $\mathrm{n} / \mathrm{a}$ & 9.9 & 4.97 & 1.83 & 1.54 & 6,519 & 0.00 & 0.37 & $\mathrm{n} / \mathrm{a}$ & $\mathrm{n} / \mathrm{a}$ \\
\hline
\end{tabular}




\begin{tabular}{|c|c|c|c|c|c|c|c|c|c|c|c|c|}
\hline Kuwait & -8.13 & $\mathrm{n} / \mathrm{a}$ & $\mathrm{n} / \mathrm{a}$ & $\mathrm{n} / \mathrm{a}$ & 6.95 & 4.51 & 0.59 & 5,298 & 0.31 & 0.53 & 80 & 40 \\
\hline Lebanon & -11.26 & $\mathrm{n} / \mathrm{a}$ & $\mathrm{n} / \mathrm{a}$ & 2.1 & 5.38 & 1.54 & 5.52 & 5,191 & $\mathrm{n} / \mathrm{a}$ & 0.13 & 50 & 65 \\
\hline Lithuania & -3.58 & 3.42 & 3.25 & $\mathrm{n} / \mathrm{a}$ & 5.51 & 3.08 & 1.52 & 3,732 & 0.00 & 0.50 & 65 & 19 \\
\hline Malaysia & -6.07 & 0.16 & 3.43 & 67.4 & 7.02 & 0.71 & 1.13 & 8,777 & 0.00 & 2.49 & 36 & 50 \\
\hline Mauritius & -9.73 & 1.73 & $\mathrm{n} / \mathrm{a}$ & $\mathrm{n} / \mathrm{a}$ & 6.54 & 6.12 & 1.39 & 8,967 & 0.34 & 0.05 & $\mathrm{n} / \mathrm{a}$ & $\mathrm{n} / \mathrm{a}$ \\
\hline Mexico & -4.52 & 2.30 & 7.94 & 19.7 & 5.03 & 1.60 & 1.38 & 10,123 & 0.11 & 1.51 & 82 & 69 \\
\hline Netherlands & -1.89 & 1.76 & 3.12 & 196.7 & 8.45 & 9.15 & 0.00 & 4,894 & 0.03 & 5.08 & 53 & 14 \\
\hline New Zealand & -5.40 & 2.60 & 7.87 & 7.9 & 8.06 & 7.62 & 0.06 & 15,002 & 0.35 & 0.30 & 49 & 58 \\
\hline Norway & -3.74 & 2.00 & 5.31 & 29.8 & 8.18 & 5.37 & 0.00 & 4,654 & 0.00 & 1.11 & 50 & 8 \\
\hline Pakistan & -11.20 & -6.73 & $\mathrm{n} / \mathrm{a}$ & 0.4 & 4.03 & 0.77 & 5.98 & 6,523 & 0.34 & 0.32 & 70 & 50 \\
\hline Philippines & -6.42 & 0.91 & 5.28 & 8.5 & 4.46 & 0.77 & 3.25 & 9,227 & 0.32 & 0.67 & 44 & 64 \\
\hline Poland & -3.73 & 1.82 & 8.35 & 2.7 & 5.14 & 1.75 & 1.00 & 4,110 & 0.00 & 1.72 & 93 & 64 \\
\hline Portugal & -4.87 & 2.31 & 1.99 & 106.7 & 6.69 & 5.78 & 1.13 & 5,184 & 0.03 & 0.67 & 99 & 31 \\
\hline Romania & -5.69 & 0.19 & 5.71 & 0.8 & 4.49 & 6.68 & 2.87 & 4,136 & 0.00 & 0.83 & 90 & 42 \\
\hline Russia & -4.16 & -2.69 & 6.32 & 6.3 & 3.27 & 4.64 & 1.46 & 4,815 & 0.00 & 5.72 & 95 & 36 \\
\hline Singapore & -5.85 & 0.24 & 2.93 & 36.1 & 8.72 & 6.45 & 0.04 & 8,843 & 0.38 & 3.47 & 8 & 48 \\
\hline Slovenia & -5.56 & 1.83 & 2.61 & 15.5 & 5.70 & 3.44 & 0.96 & 3,731 & 0.00 & 0.32 & 88 & 19 \\
\hline South Africa & -6.03 & 2.01 & 12.05 & 25.6 & 7.39 & 0.77 & 1.13 & 8,872 & 0.35 & 0.93 & 49 & 63 \\
\hline South Korea & -6.03 & 1.06 & 7.11 & 69.0 & 6.35 & 4.48 & 1.00 & 8,439 & 0.35 & 3.37 & 85 & 39 \\
\hline Spain & -3.82 & 1.60 & 2.67 & 123.0 & 6.57 & 4.18 & 0.35 & 5,310 & 0.10 & 3.46 & 86 & 42 \\
\hline Sweden & -3.28 & 2.18 & 4.94 & 105.9 & 8.58 & 3.64 & 0.05 & 4,708 & 0.03 & 2.28 & 29 & 5 \\
\hline Switzerland & -3.63 & 1.76 & 4.56 & 104.5 & 8.90 & 5.20 & 0.00 & 4,724 & 0.18 & 2.44 & 58 & 70 \\
\hline Thailand & -9.07 & 0.12 & 3.75 & 16.2 & 5.36 & 1.54 & 1.39 & 8,409 & 0.35 & 1.61 & 64 & 34 \\
\hline Turkey & -5.05 & 1.20 & 12.85 & 1.5 & 4.95 & 2.20 & 4.04 & 4,574 & 0.00 & 1.63 & 85 & 45 \\
\hline Ukraine & -5.02 & 1.92 & $\mathrm{n} / \mathrm{a}$ & 3.5 & 2.93 & 0.52 & 5.07 & 4,202 & 0.00 & 0.83 & $\mathrm{n} / \mathrm{a}$ & $\mathrm{n} / \mathrm{a}$ \\
\hline United Kingdom & -2.05 & 1.60 & 5.17 & 101.8 & 8.38 & 8.27 & 0.00 & 5,218 & 0.37 & 7.11 & 35 & 66 \\
\hline United States & -2.66 & 1.50 & 4.33 & 141.0 & 7.74 & 5.54 & 0.00 & 8,913 & 0.37 & 17.62 & 46 & 62 \\
\hline Overall Average & -5.07 & 1.54 & 5.52 & 62.8 & 6.74 & 4.70 & 1.32 & 6,686 & 0.16 & 2.9 & 64.5 & 50.3 \\
\hline
\end{tabular}

Panel B: Developed versus Emerging Markets

\begin{tabular}{|c|c|c|c|c|c|c|c|c|c|c|c|c|}
\hline & FBIAS & YLD (\%) & $\mathrm{EXCH}(\%)$ & $\begin{array}{r}\text { BDEV } \\
\text { (\% GDP) }\end{array}$ & $\begin{array}{r}\text { PROP (0- } \\
10)\end{array}$ & $\begin{array}{r}\text { CAPOP } \\
(0-10)\end{array}$ & CRISK & $\begin{array}{r}\text { DIST } \\
(\mathrm{km})\end{array}$ & $\begin{array}{c}\text { COMLA } \\
\text { (average) }\end{array}$ & $\begin{array}{r}\text { BILTR } \\
(\%)\end{array}$ & $\begin{array}{r}\text { UNTAV } \\
(1-100)\end{array}$ & $\begin{array}{c}\text { MASC } \\
(1-100)\end{array}$ \\
\hline Developed & -3.93 & 1.75 & 4.16 & 95.9 & 7.92 & 6.13 & 0.33 & 6,321 & 0.18 & 4.2 & 59.1 & 50.0 \\
\hline
\end{tabular}

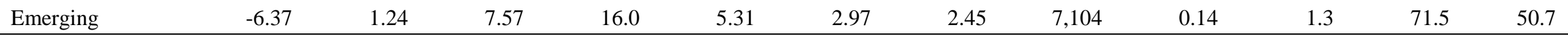




\section{Table III}

\section{Regression Analysis of Foreign Bias}

The dependent variable is foreign bias (FBIAS), the log ratio of the share of a host country (country j) in bond holdings of a source country (country $i$ ) to the world bond market weight of country $j$. Two sets of regressors are included: i) Economic Fundamentals for host country $j$ and ii) bilateral and investor-specific Familiarity Factors. Economic Fundamentals include annual yield on long-term government bonds (YLD) net of inflation and sovereign risk, $\log$ (natural) of exchange rate volatility (EXCH), log of bond market development (BDEV), protection of property rights $(P R O P)$, capital openness $(C A P O P)$, and country risk (CRISK). Familiarity Factors include log of kilometer distance between countries (DIST), common language (COMLA) dummy, average bilateral trade weight assigned by partner countries (BILTR), uncertainty avoidance (UNTAV) of source country, and masculinity (MASC) of source country. INSB equals one minus home bias of source country $i$ and controls for the obvious impact of country $i$ 's domestic bias. All variables are constructed or sourced as reported in Tabe l. All models report results with the standard errors corrected for heteroscedasticity at panel level using White (1980) method. VARD shows relative importance of variables using variance decomposition analysis. Data is for years 2001 to 2012 . Statistical significance is reported against $10 \%(*), 5 \%(* *)$ and $1 \%(* * *)$ significance levels. $t$-statistics are shown in parenthesis.

\begin{tabular}{|c|c|c|c|c|c|c|c|}
\hline & $\begin{array}{c}\text { Expected } \\
\text { Sign }\end{array}$ & Model I & Model II & Model III & Model IV & VARD & $\begin{array}{l}\text { Standardized } \\
\text { Coefficients }\end{array}$ \\
\hline YLD & + & $\begin{array}{c}0.05 * * * \\
(3.01)\end{array}$ & & $\begin{array}{c}0.05 * * * \\
(3.11)\end{array}$ & $\begin{array}{c}0.06 * * \\
(2.31)\end{array}$ & $0.05 \%$ & 0.038 \\
\hline EXCH & - & $\begin{array}{c}-0.81 * * * \\
(-3.99)\end{array}$ & & $\begin{array}{c}-0.81 * * * \\
(-9.78)\end{array}$ & $\begin{array}{c}-0.51 * * * \\
(-4.68)\end{array}$ & $2.70 \%$ & -0.056 \\
\hline BDEV & + & $\begin{array}{c}0.31 * * * \\
(2.84)\end{array}$ & & $\begin{array}{c}0.37 * * * \\
(7.79)\end{array}$ & $\begin{array}{c}0.53^{* * * *} \\
(3.01)\end{array}$ & $7.30 \%$ & 0.109 \\
\hline PROP & + & $\begin{array}{l}0.15^{* * *} \\
(2.54)\end{array}$ & & $\begin{array}{c}0.25 * * * \\
(3.14)\end{array}$ & $\begin{array}{l}0.09 * * \\
(2.06)\end{array}$ & $1.20 \%$ & 0.023 \\
\hline CAPOP & + & $\begin{array}{l}0.06^{* * *} \\
(2.51)\end{array}$ & & $\begin{array}{l}0.11^{* *} \\
(2.54)\end{array}$ & $\begin{array}{c}0.03 * * \\
(2.56)\end{array}$ & $0.03 \%$ & 0.006 \\
\hline CRISK & - & $\begin{array}{c}-0.19 * * * \\
(-2.98)\end{array}$ & & $\begin{array}{c}-0.23 * * * \\
(-2.99)\end{array}$ & $\begin{array}{c}-0.17 * * * \\
(-3.09)\end{array}$ & $0.04 \%$ & -0.029 \\
\hline DIST & - & & $\begin{array}{c}-2.65 * * * \\
(-24.35)\end{array}$ & $\begin{array}{c}-2.63 * * * \\
(-23.33)\end{array}$ & $\begin{array}{c}-2.33 * * * \\
(-20.79)\end{array}$ & $55.4 \%$ & -0.369 \\
\hline COMLA & + & & $\begin{array}{c}0.76^{* * * *} \\
(2.82)\end{array}$ & $\begin{array}{c}0.66 * * \\
(2.49)\end{array}$ & $\begin{array}{c}0.82 * * * * \\
(3.88)\end{array}$ & $1.50 \%$ & 0.037 \\
\hline BILTR & + & & $\begin{array}{c}0.05 * * * \\
(5.37)\end{array}$ & $\begin{array}{c}0.03 * * * \\
(5.54)\end{array}$ & $\begin{array}{c}0.02 * * * * \\
(3.39)\end{array}$ & $0.06 \%$ & 0.001 \\
\hline UNTAV & - & & $\begin{array}{c}-0.06 * * * \\
(-17.00)\end{array}$ & $\begin{array}{c}-0.06 * * * \\
(-16.40)\end{array}$ & $\begin{array}{c}-0.05 * * * \\
(-12.86)\end{array}$ & $28.20 \%$ & -0.266 \\
\hline MASC & + & & $\begin{array}{c}0.04 * * * \\
(8.92)\end{array}$ & $\begin{array}{c}0.03 * * * \\
(8.08)\end{array}$ & $\begin{array}{c}0.02 * * * * \\
(3.46)\end{array}$ & $2.30 \%$ & 0.122 \\
\hline INSB & + & & & & $\begin{array}{c}0.80^{* * * *} \\
(15.98)\end{array}$ & & \\
\hline $\begin{array}{l}\text { Year Fixed } \\
\text { Host Country Fixed }\end{array}$ & & YES & YES & YES & $\begin{array}{l}\text { YES } \\
\text { YES }\end{array}$ & & \\
\hline Constant & & $\begin{array}{c}-8.06 * * * \\
(-8.28)\end{array}$ & $\begin{array}{c}-1.42 * * \\
(-2.26)\end{array}$ & $\begin{array}{c}-7.08 * * * \\
(-7.38)\end{array}$ & $\begin{array}{c}-0.88 \\
(-0.85)\end{array}$ & & \\
\hline $\begin{array}{l}\text { Adjusted } \mathrm{R}^{2} \\
\text { Observations }\end{array}$ & & $\begin{array}{c}0.08 \\
14102\end{array}$ & $\begin{array}{c}0.28 \\
14102\end{array}$ & $\begin{array}{c}0.29 \\
14102\end{array}$ & $\begin{array}{c}0.34 \\
14102\end{array}$ & & \\
\hline
\end{tabular}




\section{Table IV}

\section{Examining Reverse Causality}

The dependent variable is foreign bias (FBIAS), the log ratio of the share of a host country (country $j$ ) in bond holdings of a source country (country i) to the world bond market weight of country $j$. Two sets of regressors are included: i) Economic Fundamentals for host country $j$ and ii) bilateral and investor-specific Familiarity Factors. Economic Fundamentals include annual yield on long-term government bonds (YLD) net of inflation and sovereign risk, $\log$ (natural) of exchange rate volatility (EXCH), $\log$ of bond market development $(B D E V)$, protection of property rights $(P R O P)$, capital openness $(C A P O P)$, and country risk (CRISK). Familiarity Factors include log of kilometer distance between countries (DIST), common language (COMLA) dummy, average bilateral trade weight assigned by partner countries (BILTR), uncertainty avoidance (UNTAV) of source country, and masculinity $(M A S C)$ of source country. INSB equals one minus home bias of source country $i$ and controls for the obvious impact of country $i$ 's domestic bias. All variables are constructed or sourced as (1980) method. Data is for years 2001 to 2012 . Statistical significance is reported against $10 \%(*), 5 \%(* *)$ and $1 \%(* *)$ significance levels. $t$-statistics are shown in parenthesis.

\begin{tabular}{|c|c|c|c|c|c|}
\hline 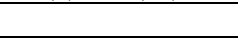 & Expected Sign & Model I & Model II & Model III & Model IV \\
\hline YLD & + & $\begin{array}{l}0.05 * * \\
(2.30)\end{array}$ & & $\begin{array}{l}0.05 * * \\
(2.41)\end{array}$ & $\begin{array}{c}0.06^{* * * *} \\
(2.87)\end{array}$ \\
\hline EXCH & - & $\begin{array}{c}-0.68 * * * \\
(-3.36)\end{array}$ & & $\begin{array}{c}-0.75 * * * \\
(-4.04)\end{array}$ & $\begin{array}{c}-0.55^{* * * *} \\
(-3.98)\end{array}$ \\
\hline BDEV (1-yr lag) & + & $\begin{array}{l}0.27 * * \\
(2.52)\end{array}$ & & $\begin{array}{l}0.39 * * \\
(2.15)\end{array}$ & $\begin{array}{l}0.45^{* * * *} \\
(3.13)\end{array}$ \\
\hline PROP (1-yr lag) & + & $\begin{array}{c}0.18^{* * * *} \\
(3.07)\end{array}$ & & $\begin{array}{c}0.17 * * * \\
(3.44)\end{array}$ & $\begin{array}{l}0.09^{* *} \\
(2.41)\end{array}$ \\
\hline CAPOP (1-yr lag) & + & $\begin{array}{c}0.05 * * * \\
(2.91)\end{array}$ & & $\begin{array}{l}0.07 * * \\
(2.19)\end{array}$ & $\begin{array}{l}0.04 * \\
(1.77)\end{array}$ \\
\hline CRISK (1-yr lag) & - & $\begin{array}{l}-0.17 * * \\
(-2.23)\end{array}$ & & $\begin{array}{c}-0.24 * * * \\
(-3.23)\end{array}$ & $\begin{array}{c}-0.20 * * * \\
(-2.91)\end{array}$ \\
\hline DIST & - & & $\begin{array}{l}-2.51 * * * \\
(-22.25)\end{array}$ & $\begin{array}{c}-2.51 * * * \\
(-21.26)\end{array}$ & $\begin{array}{c}-1.92 * * * \\
(-19.31)\end{array}$ \\
\hline COMLA & + & & $\begin{array}{c}0.67 * * \\
(2.52)\end{array}$ & $\begin{array}{l}0.55^{* *} \\
(2.08)\end{array}$ & $\begin{array}{l}0.72 * * * \\
(3.25)\end{array}$ \\
\hline BILTR (1-yr lag) & + & & $\begin{array}{l}0.08 * * * \\
(5.07)\end{array}$ & $\begin{array}{l}0.08^{* *} \\
(2.26)\end{array}$ & $\begin{array}{c}0.02 * * * \\
(3.37)\end{array}$ \\
\hline UNTAV & - & & $\begin{array}{c}-0.07 * * * \\
(-16.89)\end{array}$ & $\begin{array}{c}-0.06^{* * * *} \\
(-16.12)\end{array}$ & $\begin{array}{c}-0.05 * * * \\
(-13.24)\end{array}$ \\
\hline MASC & + & & $\begin{array}{c}0.04 * * * \\
(9.37)\end{array}$ & $\begin{array}{c}0.04 * * * \\
(8.45)\end{array}$ & $\begin{array}{l}0.02 * * * \\
(3.97)\end{array}$ \\
\hline INSB & + & & & & $\begin{array}{l}0.77 * * * \\
(14.20)\end{array}$ \\
\hline $\begin{array}{l}\text { Year Fixed } \\
\text { Host Country Fixed }\end{array}$ & & YES & YES & YES & $\begin{array}{l}\text { YES } \\
\text { YES }\end{array}$ \\
\hline Constant & & $\begin{array}{c}-7.10 * * * \\
(-6.95) \\
\end{array}$ & $\begin{array}{c}-1.27 * * \\
(-2.11) \\
\end{array}$ & $\begin{array}{c}-6.32 * * * \\
(-6.32) \\
\end{array}$ & $\begin{array}{c}-0.82 \\
(-0.88) \\
\end{array}$ \\
\hline $\begin{array}{l}\text { Adjusted } \mathrm{R}^{2} \\
\text { Observations }\end{array}$ & & $\begin{array}{c}0.08 \\
11715\end{array}$ & $\begin{array}{c}0.29 \\
11715 \\
\end{array}$ & $\begin{array}{c}0.30 \\
11715\end{array}$ & $\begin{array}{c}0.35 \\
11715\end{array}$ \\
\hline
\end{tabular}




\section{Table V}

Regression Analysis of Foreign Bias Excluding Financial Centres

The dependent variable is foreign bias (FBIAS), the log ratio of the share of a host country (country $j$ ) in bond holdings of a source country (country i) to the world bond market weight of country $j$. Two sets of regressors are included: 1) Economic Fundamentals for host country $j$ and ii) bilateral and investor-specific Familiarity Factors. Economic Fundamentals include annual yield on long-term government bonds ( $Y L D$ ) net of inflation and sovereign risk, $\log$ (natural) of exchange rate volatility (EXCH), $\log$ of bond market development $(B D E V)$, protection of property rights $(P R O P)$, capital openness $(C A P O P)$, and country risk (CRISK). Familiarity Factors include $\log$ of kilometer distance between countries (DIST), common language (COMLA) dummy, average bilateral trade weight assigned by partner countries (BILTR), uncertainty avoidance (UNTAV) of source country, and masculinity (MASC) of source country. INSB equals one minus home bias of source country $i$ and controls for the obvious impact of country $i$ 's domestic bias. All variables are constructed or sourced as


$10 \%(*), 5 \%(* *)$ and $1 \%(* * *)$ significance levels. $t$-statistics are shown in parenthesis.

\begin{tabular}{|c|c|c|c|c|c|}
\hline 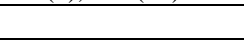 & Expected Sign & Model I & Model II & Model III & Model IV \\
\hline YLD & + & $\begin{array}{c}0.05 * * * \\
(2.87)\end{array}$ & & $\begin{array}{c}0.07 * * * \\
(2.89)\end{array}$ & $\begin{array}{c}0.07 * * * \\
(3.21)\end{array}$ \\
\hline $\mathrm{EXCH}$ & - & $\begin{array}{c}-0.66 * * * \\
(-3.63)\end{array}$ & & $\begin{array}{c}-0.64 * * * \\
(-9.50)\end{array}$ & $\begin{array}{c}-0.58 * * * \\
(-2.79)\end{array}$ \\
\hline BDEV & + & $\begin{array}{c}0.31 * * * \\
(3.05)\end{array}$ & & $\begin{array}{c}0.45^{* * *} \\
(3.21)\end{array}$ & $\begin{array}{c}0.63 * * * \\
(3.36)\end{array}$ \\
\hline PROP & + & $\begin{array}{l}0.17 * \\
(1.83)\end{array}$ & & $\begin{array}{c}0.27 * * * \\
(2.86)\end{array}$ & $\begin{array}{c}0.07 * * \\
(2.06)\end{array}$ \\
\hline CAPOP & + & $\begin{array}{l}0.10 * * \\
(2.69)\end{array}$ & & $\begin{array}{l}0.13 * * \\
(2.43)\end{array}$ & $\begin{array}{c}0.05^{* *} \\
(2.31)\end{array}$ \\
\hline CRISK & - & $\begin{array}{c}-0.24 * * * \\
(-2.78)\end{array}$ & & $\begin{array}{c}-0.25 * * * \\
(-2.71)\end{array}$ & $\begin{array}{l}-0.18 * * \\
(-2.58)\end{array}$ \\
\hline DIST & - & & $\begin{array}{c}-3.00 * * * \\
(-24.53)\end{array}$ & $\begin{array}{c}-3.00 * * * \\
(-23.48)\end{array}$ & $\begin{array}{c}-2.23 * * * \\
(-19.59)\end{array}$ \\
\hline COMLA & + & & $\begin{array}{l}0.73 * * \\
(2.31)\end{array}$ & $\begin{array}{l}0.61 * * \\
(2.15)\end{array}$ & $\begin{array}{c}0.95^{* * *} \\
(3.56)\end{array}$ \\
\hline BILTR & + & & $\begin{array}{c}0.07 * * * \\
(4.99)\end{array}$ & $\begin{array}{c}0.08 * * * \\
(3.14)\end{array}$ & $\begin{array}{c}0.03 * * * \\
(2.94)\end{array}$ \\
\hline UNTAV & - & & $\begin{array}{c}-0.05 * * * \\
(-10.21)\end{array}$ & $\begin{array}{c}-0.05 * * * \\
(-9.65)\end{array}$ & $\begin{array}{c}-0.04 * * * \\
(-7.32)\end{array}$ \\
\hline MASC & + & & $\begin{array}{c}0.03 * * \\
(2.53)\end{array}$ & $\begin{array}{l}0.02 * * \\
(2.36)\end{array}$ & $\begin{array}{l}0.02 * * \\
(2.26)\end{array}$ \\
\hline INSB & + & & & & $\begin{array}{c}0.89 * * * \\
(6.33)\end{array}$ \\
\hline $\begin{array}{l}\text { Year Fixed } \\
\text { Host Country Fixed }\end{array}$ & & YES & YES & YES & $\begin{array}{l}\text { YES } \\
\text { YES }\end{array}$ \\
\hline Constant & & $\begin{array}{c}-9.09 * * * \\
(-8.05) \\
\end{array}$ & $\begin{array}{c}-1.09 \\
(-1.40)\end{array}$ & $\begin{array}{c}-7.89 * * * \\
(-6.73) \\
\end{array}$ & $\begin{array}{l}-1.50 \\
(-1.22) \\
\end{array}$ \\
\hline $\begin{array}{l}\text { Adjusted } \mathrm{R}^{2} \\
\text { Observations }\end{array}$ & & $\begin{array}{c}0.10 \\
11539\end{array}$ & $\begin{array}{c}0.28 \\
11539\end{array}$ & $\begin{array}{c}0.29 \\
11539\end{array}$ & $\begin{array}{c}0.33 \\
11539\end{array}$ \\
\hline
\end{tabular}


Table VI

\section{Examining Foreign Bias During Crises And Normal Times}

Foreign bias (FBIAS) is the log ratio of the share of a host country (country j) in bond holdings of a source country (country $i$ ) to the world bond market weight of country $j$. This table shows the comparative average foreign bias of country $j$ during crisis and non-crisis periods using a t-test. Crisis periods include global financial crisis (2007-2008) and Eurozone sovereign debt crisis

$(2009-2011)$

Panel A: Foreign Bias - Normal Period versus Global Financial Crisis (2007-08) and Eurozone Debt Crisis (2009-11)

\begin{tabular}{lrrrr} 
& $2001-06,2012$ & $2007-2011$ & Difference & t-statistics \\
\hline FBIAS & -4.867 & -5.289 & 0.422 & 4.610 \\
\hline No. of Observations & 20123 & & & \\
\hline
\end{tabular}
0.000

Panel B: Foreign Bias - Normal Period versus Global Financial Crisis (2007-08)

\begin{tabular}{|c|c|c|c|c|c|}
\hline & $2001-06,2012$ & $2007-08$ & Difference & t- statistics & $p$-value \\
\hline FBIAS & -4.867 & -4.716 & -0.151 & -1.211 & 0.226 \\
\hline No. of Observations & 13845 & & & & \\
\hline \multicolumn{6}{|c|}{ Panel C: Foreign Bias - Normal Period versus Eurozone Debt Crisis (2009-11) } \\
\hline & $2001-06,2012$ & $2009-11$ & Difference & t- statistics & p-value \\
\hline FBIAS & -4.867 & -5.599 & 0.732 & 6.985 & 0.000 \\
\hline
\end{tabular}

16735

Difference

0.813

t- statistics

2.933

p-value

\begin{tabular}{lrrrr} 
& $2001-06,2012$ & $2009-11$ & Difference & p-value \\
\hline FBIAS & -3.616 & -4.428 & 0.813 & 0.003 \\
\hline No. of Observations & 2101 & & 2.933 & t statistics \\
\hline
\end{tabular}

No. of Observations 210 
Table VII

\section{Bond Foreign Bias During Eurozone Debt Crisis and Global Financial Crisis}

The dependent variable is foreign bias (FBIAS), the log ratio of the share of a host country (country j) in bond holdings of a source country (country $i$ ) to the world bond market weight of country j. GIIPSCr is an interaction term of ECrisis and GIIPS. ECrisis is a dummy variable of 1 for Eurozone crisis years 2009 - 2011 and GIIPS is a dummy variable of 1 for five Eurozone crisis countries namely Greece, Italy, Ireland, Portugal and Spain (GIIPS), 0 otherwise. EuZCr is an interaction term of ECrisis and EZone. EZone is a dummy variable of 1 for all countries within the European Monetary Union, 0 otherwise. GCrisis is a dummy variable of 1 for Global Financial crisis years 2007 - 2008; 0 otherwise. Other regressors include: i) Economic Fundamentals for host country $j$ and ii) bilateral and investor-specific Familiarity Factors. Economic Fundamentals include annual yield on long-term government bonds $(Y L D)$ net of inflation and sovereign risk, log (natural) of exchange rate volatility (EXCH), log of bond market development $(B D E V)$, protection of property rights $(P R O P)$, capital openness (CAPOP), and country risk (CRISK). Familiarity Factors include log of kilometer distance between countries (DIST), common language (COMLA) dummy, average bilateral trade weight assigned by partner countries (BILTR), uncertainty avoidance (UNTAV) of source country, and masculinity (MASC) of source country. INSB equals one minus home bias of source country $i$ and controls for the obvious impact of country $i$ 's countries (BILTR), uncertainty avoidance (UNTAV) of source country, and masculinity (MASC) of source country. INSB equals one minus home bias of source country $i$ and controls for the obvious impact of country $i$ 's
domestic bias. All variables are constructed or sourced as reported in Table 1 . All models report results with the standard errors corrected for heteroscedasticity at panel level using White (1980) method. Data is for years 2001 to 2012. Statistical significance is reported against $10 \%(*), 5 \%(* *)$ and $1 \%(* * *)$ significance levels. $t$-statistics are shown in parenthesis.

\begin{tabular}{|c|c|c|c|c|}
\hline & $\begin{array}{c}\text { Model I } \\
\text { All Countries }\end{array}$ & $\begin{array}{c}\text { Model II } \\
\text { Interaction with EMU }\end{array}$ & $\begin{array}{c}\text { Model III } \\
\text { Interaction with EMU except Germany and } \\
\text { France }\end{array}$ & $\begin{array}{c}\text { Model IV } \\
\text { Interaction with GIIPS }\end{array}$ \\
\hline ECrisis & $\begin{array}{c}-0.47 * * * \\
(-3.97)\end{array}$ & $\begin{array}{c}-0.55^{* * * *} \\
(-3.95)\end{array}$ & $\begin{array}{c}-0.47 * * * \\
(-3.61)\end{array}$ & $\begin{array}{c}-0.46 * * * \\
(-3.76)\end{array}$ \\
\hline GCrisis & $\begin{array}{c}0.15 \\
(1.45)\end{array}$ & $\begin{array}{l}0.15 \\
(1.45)\end{array}$ & $\begin{array}{l}0.15 \\
(1.45)\end{array}$ & $\begin{array}{l}0.15 \\
(1.45)\end{array}$ \\
\hline $\mathrm{EuZCr}$ & & $\begin{array}{c}-0.14 \\
(-0.62)\end{array}$ & $\begin{array}{l}-0.12 * \\
(-1.86)\end{array}$ & \\
\hline EZone & & $\begin{array}{c}0.62 * * * \\
(2.74)\end{array}$ & $\begin{array}{c}0.38 \\
(1.60)\end{array}$ & \\
\hline GIIPSCr & & & & $\begin{array}{c}-0.24 * * \\
(-2.39)\end{array}$ \\
\hline GIIPS & & & & $\begin{array}{c}0.17 \\
(0.61)\end{array}$ \\
\hline YLD & $\begin{array}{c}0.03 * * \\
(2.52)\end{array}$ & $\begin{array}{l}0.02 * \\
(1.88)\end{array}$ & $\begin{array}{l}0.02 * \\
(1.84)\end{array}$ & $\begin{array}{c}0.03^{* * *} \\
(3.11)\end{array}$ \\
\hline EXCH & $\begin{array}{c}-1.31 * * * * \\
(-5.87)\end{array}$ & $\begin{array}{c}-1.26 * * * \\
(-5.75)\end{array}$ & $\begin{array}{c}-1.26 * * * \\
(-5.69)\end{array}$ & $\begin{array}{c}-1.31 * * * \\
(-5.95)\end{array}$ \\
\hline BDEV & $\begin{array}{l}0.54 * * * \\
(4.25)\end{array}$ & $\begin{array}{l}0.58 * * * \\
(3.77)\end{array}$ & $\begin{array}{c}0.58 * * * \\
(3.76)\end{array}$ & $\begin{array}{c}0.61 * * * \\
(4.12)\end{array}$ \\
\hline PROP & $\begin{array}{l}0.18^{* *} \\
(2.39)\end{array}$ & $\begin{array}{c}0.19 * * \\
(2.50)\end{array}$ & $\begin{array}{c}0.19 * * \\
(2.50)\end{array}$ & $\begin{array}{l}0.06^{*} \\
(1.94)\end{array}$ \\
\hline CAPOP & $\begin{array}{l}0.08 * * \\
(2.37)\end{array}$ & $\begin{array}{l}0.08^{* *} \\
(2.44)\end{array}$ & $\begin{array}{l}0.08^{* *} \\
(2.42)\end{array}$ & $\begin{array}{l}0.11 * * \\
(2.37)\end{array}$ \\
\hline CRISK & $\begin{array}{c}-0.28 * * * \\
(-3.58)\end{array}$ & $\begin{array}{c}-0.29 * * * \\
(-3.64)\end{array}$ & $\begin{array}{c}-0.29 * * * \\
(-3.66)\end{array}$ & $\begin{array}{c}-0.28 * * * \\
(-3.60)\end{array}$ \\
\hline DIST & $\begin{array}{l}-2.32 * * * \\
(-20.74)\end{array}$ & $\begin{array}{l}-2.32 * * * \\
(-20.74)\end{array}$ & $\begin{array}{l}-2.32 * * * \\
(-20.45\end{array}$ & $\begin{array}{l}-2.32 * * * \\
(-20.74)\end{array}$ \\
\hline COMLA & $\begin{array}{c}1.01 * * * \\
(3.89)\end{array}$ & $\begin{array}{c}1.00^{* * *} \\
(3.89)\end{array}$ & $\begin{array}{c}1.00^{* * *} \\
(3.77)\end{array}$ & $\begin{array}{c}1.01 * * * \\
(3.89)\end{array}$ \\
\hline BILTR & $\begin{array}{l}0.02 * * \\
(2.30)\end{array}$ & $\begin{array}{l}0.03 * * \\
(2.31)\end{array}$ & $\begin{array}{c}0.03 * * \\
(2.31)\end{array}$ & $\begin{array}{l}0.02 * * \\
(2.32)\end{array}$ \\
\hline UNTAV & $\begin{array}{l}-0.05 * * * \\
(-12.83)\end{array}$ & $\begin{array}{l}-0.05 * * * \\
(-12.83)\end{array}$ & $\begin{array}{l}-0.05 * * * \\
(-12.22)\end{array}$ & $\begin{array}{l}-0.05^{* * *} \\
(-12.83)\end{array}$ \\
\hline MASC & $\begin{array}{c}0.02^{* * *} \\
(3.45)\end{array}$ & $\begin{array}{c}0.02^{* * * *} \\
(3.45)\end{array}$ & $\begin{array}{c}0.02 * * * * \\
(3.46)\end{array}$ & $\begin{array}{c}0.02 * * * \\
(3.45)\end{array}$ \\
\hline INSB & $\begin{array}{c}0.79 * * * \\
(15.89)\end{array}$ & $\begin{array}{c}0.79 * * * \\
(15.89)\end{array}$ & $\begin{array}{c}0.79 * * * \\
(15.25)\end{array}$ & $\begin{array}{c}0.79 * * * \\
(15.89)\end{array}$ \\
\hline $\begin{array}{l}\text { Host Country Fixed } \\
\text { Constant }\end{array}$ & $\begin{array}{l}\text { YES } \\
-1.75^{*} \\
(-1.80)\end{array}$ & $\begin{array}{l}\text { YES } \\
-1.60^{*} \\
(-1.65)\end{array}$ & $\begin{array}{l}\text { YES } \\
-1.76^{*} \\
(-1.82)\end{array}$ & $\begin{array}{l}\text { YES } \\
-1.79^{*} \\
(-1.85)\end{array}$ \\
\hline $\begin{array}{l}\text { Adjusted R }{ }^{2} \\
\text { Observations }\end{array}$ & $\begin{array}{c}0.34 \\
14102\end{array}$ & $\begin{array}{c}0.34 \\
14102\end{array}$ & $\begin{array}{c}0.34 \\
14102\end{array}$ & $\begin{array}{c}0.34 \\
14102 \\
\end{array}$ \\
\hline
\end{tabular}




\section{Table VIII}

Importance of Economic and Non-Economic Factors During Eurozone Debt Crisis

The dependent variable is foreign bias (FBIAS), the log ratio of the share of a host country (country $j$ ) in bond holdings of a source country (country $i$ ) to the world bond market weight of country $j$. Two sets of regressors are included: i) Economic Fundamentals for host country $j$ and ii) bilateral and investor-specific Familiarity Factors. Economic Fundamentals include annual yield on long-term government bonds (YLD) net of inflation and sovereign risk, log (natural) of exchange rate volatility (EXCH), log of bond market development (BDEV), protection of property rights $(P R O P)$, capital openness $(C A P O P)$; country risk (CRISK) and are represented by FactorFund using factor analysis. Familiarity Factors include log of distance (in kilometers) between countries (DIST), common language (COMLA), average bilateral trade weight assigned by partner countries (BILTR), uncertainty avoidance (UNTAV) of source country, and masculinity (MASC) of source country; and are represented by FactorFam using factor analysis. INSB equals one minus domestic bias for source country $i$ and controls for the obvious impact of country $i$ 's domestic allocation as a share of total investment. CrFundW (CrFamW) is an interaction term between FactorFund (FactorFam) and ECrisis. ECrisis is a dummy variable of 1 for years 2009-2011; otherwise 0. CrFundEu (CrFamEu) is an interaction term between FactorFund (FactorFam) and a dummy variable of 1 for all Eurozone countries during years 2009-2011, otherwise 0. CrFund5 (CrFam5) is an interaction term between FactorFund (FactorFam) and a dummy variable of 1 for five countries Greece, Ireland, Italy, Portugal, and Spain (GIIPS) during years 2009-2011, otherwise 0 . All models report results with is an interaction term between FactorFund (FactorFam) and a dummy variable of 1 for five countries Greece, Ireland, Italy, Portugal, and Spain (GIIPS) during years 2009-2011, otherwise 0. All models report results with
the standard errors corrected for heteroscedasticity at panel level using White (1980) method. Data is for years 2001 to 2012 . Statistical significance is reported against $10 \%$ (*), $5 \%$ (**) and $1 \%$ (***) significance levels. $t$ statistics are shown in parenthesis.
Model I
Model II
Model III

Interaction with All

Interaction with Eurozone

$0.83 * * *$

$0.79 * * *$

Interaction with GIIPS

\begin{tabular}{lc}
\hline FactorFund & $0.83^{* * *}$ \\
& $(4.25)$ \\
FactorFam & $-2.96^{* * *}$ \\
& $(-11.87)$ \\
CrFundW & 0.13 \\
& $(1.19)$ \\
CrFamW & $-1.06^{* * *}$ \\
& $(-5.26)$
\end{tabular}

CrFundEu

CrFamEu

$-1.06 * *$

$(-2.56)$

CrFund5

$(-0.06)$

CrFam5

$-2.67 * * *$

INSB

$1.04 * * *$

$1.04 * * *$

$(21.01)$

(20.97)

$1.05 * * *$

YES

YES

YES

Host Country Fixed

$2.06 * * *$

$1.81 * *$

$176 * * *$

Constant

(2.78)

Adjusted R ${ }^{2}$

0.28

(2.47)

(2.43)

Observations

14102

14102

0.28 


\section{Appendix 1}

\section{Regression Analysis of Foreign Bias - FBIAS into Emerging and Developed Markets}

This table exhibits separate regression for foreign bias (FBIAS) into Emerging Markets (Column I) and Developed Markets (Column II). The dependent variable is FBIAS, the log ratio of the share of a host country (country $j$ ) in bond holdings of a source country (country $i$ ) to the world bond market weight of country $j$. Two sets of regressors are included: i) Economic Fundamentals for host country $j$ and ii) bilateral and investorspecific Familiarity Factors. Economic Fundamentals include annual yield on long-term government bonds (YLD) net of inflation and sovereign risk, log (natural) of exchange rate volatility (EXCH), log of bond market development $(B D E V)$, protection of property rights (PROP), capital openness (CAPOP), and country risk (CRISK). Familiarity Factors include log of kilometer distance between countries (DIST), common language (COMLA) dummy, average bilateral trade weight assigned by partner countries (BILTR), uncertainty avoidance (UNTAV) of source country, and masculinity (MASC) of source country. INSB equals one minus home bias of source country $i$ and controls for the obvious impact of country $i$ 's domestic bias. All variables are constructed or sourced as reported in Table 1. All models report results with the standard errors corrected for heteroscedasticity at panel level using White (1980) method. VARD shows relative importance of variables using variance decomposition analysis. Data is for years 2001 to 2012 . Statistical significance is reported against $10 \%(*), 5 \%(* *)$ and $1 \%(* * *)$ significance levels. $t$-statistics are shown in parenthesis

\begin{tabular}{|c|c|c|c|c|c|c|}
\hline 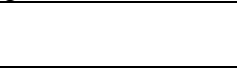 & $\begin{array}{c}\text { I } \\
\text { Into Emerging Markets } \\
\end{array}$ & $\begin{array}{c}\text { VARD } \\
\text { Emerging Markets } \\
\end{array}$ & $\begin{array}{c}\text { Standardized Coefficients } \\
\text { Emerging Markets }\end{array}$ & $\begin{array}{c}\text { II } \\
\text { Into Developed Markets } \\
\end{array}$ & $\begin{array}{c}\text { VARD } \\
\text { Developed Markets } \\
\end{array}$ & $\begin{array}{c}\text { Standardized Coefficients } \\
\text { Developed Markets }\end{array}$ \\
\hline YLD & $\begin{array}{l}0.04 * * \\
(2.03)\end{array}$ & $0.12 \%$ & 0.04 & $\begin{array}{c}0.07 * * \\
(2.35)\end{array}$ & $5.73 \%$ & 0.02 \\
\hline $\mathrm{EXCH}$ & $\begin{array}{l}-2.75 * * * \\
(-7.75)\end{array}$ & $0.75 \%$ & -0.21 & $\begin{array}{l}-1.42 * * * \\
(-5.67)\end{array}$ & $3.73 \%$ & -0.12 \\
\hline BDEV & $\begin{array}{l}0.36 * * \\
(2.54)\end{array}$ & $3.04 \%$ & 0.07 & $\begin{array}{l}0.33 * * \\
(2.59)\end{array}$ & $13.85 \%$ & 0.05 \\
\hline PROP & $\begin{array}{l}0.05^{*} \\
(1.93)\end{array}$ & $0.18 \%$ & 0.01 & $\begin{array}{c}0.33^{* * * *} \\
(3.28)\end{array}$ & $7.22 \%$ & 0.06 \\
\hline CAPOP & $\begin{array}{l}0.09 * \\
(1.92)\end{array}$ & $0.2 \%$ & 0.03 & $\begin{array}{l}0.13^{* * *} \\
(2.68)\end{array}$ & $2.14 \%$ & 0.05 \\
\hline CRISK & $\begin{array}{c}-0.10 \\
(-1.09)\end{array}$ & $0.24 \%$ & -0.02 & $\begin{array}{c}-0.42 * * * \\
(-3.67)\end{array}$ & $8.39 \%$ & -0.05 \\
\hline DIST & $\begin{array}{l}-3.32 * * * \\
(-14.61)\end{array}$ & $59.44 \%$ & -0.44 & $\begin{array}{l}-2.04 * * * \\
(-16.40)\end{array}$ & $37.63 \%$ & -0.38 \\
\hline COMLA & $\begin{array}{l}2.08 * * * * \\
(4.13)\end{array}$ & $1.75 \%$ & 0.11 & $\begin{array}{l}0.60 * * \\
(2.15)\end{array}$ & $0.78 \%$ & 0.04 \\
\hline BILTR & $\begin{array}{l}0.06^{*} \\
(1.81)\end{array}$ & $-1.93 \%$ & 0.03 & $\begin{array}{l}0.04 * * * \\
(2.67)\end{array}$ & $0.21 \%$ & 0.06 \\
\hline UNTAV & $\begin{array}{c}-0.06^{* * * *} \\
(-8.01)\end{array}$ & $30.77 \%$ & -0.21 & $\begin{array}{c}-0.04 * * * \\
(-9.77)\end{array}$ & $17.87 \%$ & -0.20 \\
\hline MASC & $\begin{array}{c}0.02 * * * \\
(2.65)\end{array}$ & $4.71 \%$ & 0.07 & $\begin{array}{l}0.02 * * \\
(2.67)\end{array}$ & $0.45 \%$ & 0.03 \\
\hline INSB & $\begin{array}{l}1.29 * * * \\
(14.34)\end{array}$ & $1.5 \% \%$ & 0.34 & $\begin{array}{c}0.61 * * * \\
(10.70)\end{array}$ & $1.3 \%$ & 0.20 \\
\hline Year Fixed & YES & & & YES & & \\
\hline Host Country Fixed & YES & & & YES & & \\
\hline Constant & $\begin{array}{c}-4.84 * * * * \\
(-3.38) \\
\end{array}$ & & & $\begin{array}{c}-3.45^{* *} \\
(-2.17) \\
\end{array}$ & & \\
\hline $\begin{array}{l}\text { Adjusted } \mathrm{R}^{2} \\
\text { Observations }\end{array}$ & $\begin{array}{l}0.39 \\
4699 \\
\end{array}$ & & & $\begin{array}{c}0.31 \\
9403 \\
\end{array}$ & & \\
\hline
\end{tabular}


Regression Analysis of Foreign Bias - Combinations of Emerging and Developed Markets

This table exhibits results for separate regressions for foreign bias (FBIAS) originating from Emerging markets (EM) and Developed markets (DM). The dependent variable is FBIAS, the log ratio of the share of a host country (country $j$ ) in bond holdings of a source country (country $i$ ) to the world bond market weight of country $j$. Two sets of regressors are included: i) Economic Fundamentals for host country $j$ and ii) bilateral and investor-specific Familiarity Factors. Economic Fundamentals include annual yield on long-term government bonds $(Y L D)$ net of inflation and sovereign risk, log (natural) of exchange rate volatility (EXCH), log of bond market development (BDEV), protection of property rights $(P R O P)$, capital openness (CAPOP), and country risk (CRISK). Familiarity Factors include log of kilometer distance between countries (DIST), common language (COMLA) dummy, average bilateral trade weight assigned by partner countries (BILTR), uncertainty avoidance (UNTAV) of source country, and masculinity (MASC) of source country. INSB equals one minus language ( $C O M L A)$ dummy, average bilateral trade weight assigned by partner countries (BLTR), uncertainty avoidance (UNTA $)$ of source country, and masculinity (MASC) of source country. INSB equals one minus
home bias of source country $i$ and controls for the obvious impact of country $i$ 's domestic bias. All variables are constructed or sourced as reported in Table 1 . All models report results with the standard errors corrected home bias of source country $i$ and controls for the obvious impact of country $i$ 's domestic bias. All variables are constructed or sourced as reported in Table 1. All models report results with the standard errors corrected
for heteroscedasticity at panel level using White (1980) method. Data is for years 2001 to 2012 . Statistical significance is reported against $10 \%(*)$, 5\% (**) and $1 \%(* * *)$ significance levels. $t$-statistics are shown in parenthesis.

\begin{tabular}{|c|c|c|c|c|c|c|}
\hline & EM to All countries & DM to All countries & EM to DM & DM to DM & EM to EM & DM to EM \\
\hline $\begin{array}{ll}\text { YLD } \\
\end{array}$ & $\begin{array}{l}0.03 * * \\
(2.56)\end{array}$ & $\begin{array}{l}0.02 * * \\
(2.42)\end{array}$ & $\begin{array}{l}0.08 * * \\
(2.18)\end{array}$ & $\begin{array}{c}0.01 \\
(1.46)\end{array}$ & $\begin{array}{l}0.07 * * \\
(2.37)\end{array}$ & $\begin{array}{l}0.02 * * \\
(2.25)\end{array}$ \\
\hline $\mathrm{EXCH}$ & $\begin{array}{c}-2.56^{* * * *} \\
(-5.42)\end{array}$ & $\begin{array}{c}-0.95 * * * \\
(-6.35)\end{array}$ & $\begin{array}{c}-1.93 * * * \\
(-3.45)\end{array}$ & $\begin{array}{c}-0.79 * * * \\
(-5.02)\end{array}$ & $\begin{array}{c}-3.67 * * * \\
(-4.26)\end{array}$ & $\begin{array}{c}-1.85 * * * \\
(-6.64)\end{array}$ \\
\hline BDEV & $\begin{array}{l}0.20^{*} \\
(1.92)\end{array}$ & $\begin{array}{l}0.13^{*} \\
(1.98)\end{array}$ & $\begin{array}{c}0.62 * * \\
(2.28)\end{array}$ & $\begin{array}{l}0.02^{*} \\
(1.95)\end{array}$ & $\begin{array}{l}0.58^{*} \\
(1.94)\end{array}$ & $\begin{array}{l}0.42 * * \\
(2.06)\end{array}$ \\
\hline PROP & $\begin{array}{c}0.37 * * \\
(1.99)\end{array}$ & $\begin{array}{c}0.17 * * * * \\
(2.86)\end{array}$ & $\begin{array}{c}0.53 * * \\
(2.28)\end{array}$ & $\begin{array}{c}0.18^{* * * *} \\
(3.36)\end{array}$ & $\begin{array}{l}0.04 * \\
(1.82)\end{array}$ & $\begin{array}{l}0.11^{*} \\
(1.96)\end{array}$ \\
\hline CAPOP & $\begin{array}{l}0.13^{*} \\
(1.71)\end{array}$ & $\begin{array}{c}0.07 * * * * \\
(2.64)\end{array}$ & $\begin{array}{l}0.09^{*} \\
(1.81)\end{array}$ & $\begin{array}{c}0.05^{* *} * \\
(2.01)\end{array}$ & $\begin{array}{l}0.20^{*} \\
(1.88)\end{array}$ & $\begin{array}{c}0.05 * * \\
(2.73)\end{array}$ \\
\hline CRISK & $\begin{array}{l}-0.27 \\
(-1.52)\end{array}$ & $\begin{array}{c}-0.12 * * \\
(-2.53)\end{array}$ & $\begin{array}{l}-0.28 \\
(-1.08)\end{array}$ & $\begin{array}{c}-0.25 * * * \\
(-4.47)\end{array}$ & $\begin{array}{c}-0.01 \\
(-0.04)\end{array}$ & $\begin{array}{c}0.12 \\
(1.27)\end{array}$ \\
\hline DIST & $\begin{array}{c}-2.92 * * * \\
(-14.80)\end{array}$ & $\begin{array}{c}-1.50 * * * \\
(-15.04)\end{array}$ & $\begin{array}{c}-2.74 * * * \\
(-12.17)\end{array}$ & $\begin{array}{c}-1.05 * * * \\
(-11.69)\end{array}$ & $\begin{array}{c}-2.83 * * * \\
(-5.74)\end{array}$ & $\begin{array}{c}-2.96^{* * * *} \\
(-12.82)\end{array}$ \\
\hline COMLA & $\begin{array}{c}2.52 * * * \\
(5.45)\end{array}$ & $\begin{array}{l}0.28^{*} \\
(1.81)\end{array}$ & $\begin{array}{c}1.83 * * * \\
(3.51)\end{array}$ & $\begin{array}{c}0.09 \\
(0.45)\end{array}$ & $\begin{array}{c}3.91 * * * \\
(4.02)\end{array}$ & $\begin{array}{l}0.98^{*} \\
(1.90)\end{array}$ \\
\hline BILTR & $\begin{array}{l}0.01^{*} \\
(1.70)\end{array}$ & $\begin{array}{l}0.03^{*} \\
(1.81)\end{array}$ & $\begin{array}{l}0.03^{*} \\
(1.82)\end{array}$ & $\begin{array}{l}0.04 * \\
(1.75)\end{array}$ & $\begin{array}{c}0.12 * * \\
(2.31)\end{array}$ & $\begin{array}{c}0.19 * * \\
(2.23)\end{array}$ \\
\hline UNTAV & $\begin{array}{c}-0.06^{* * *} \\
(-6.57)\end{array}$ & $\begin{array}{c}-0.03 * * * \\
(-8.03)\end{array}$ & $\begin{array}{c}-0.05 * * * \\
(-5.57)\end{array}$ & $\begin{array}{c}-0.02 * * * \\
(-5.38)\end{array}$ & $\begin{array}{c}-0.06 * * * \\
(-3.07)\end{array}$ & $\begin{array}{c}-0.05 * * * \\
(-6.61)\end{array}$ \\
\hline MASC & $\begin{array}{c}0.05 * * * \\
(2.88)\end{array}$ & $\begin{array}{c}0.03 * * * * \\
(7.03)\end{array}$ & $\begin{array}{c}0.04 * * * * \\
(3.13)\end{array}$ & $\begin{array}{c}0.02 * * * \\
(3.74)\end{array}$ & $\begin{array}{c}0.07 * * * \\
(3.42)\end{array}$ & $\begin{array}{c}0.04 * * * \\
(5.93)\end{array}$ \\
\hline INSB & $\begin{array}{c}0.02 \\
(0.18)\end{array}$ & $\begin{array}{c}0.19 * * * \\
(3.44)\end{array}$ & $\begin{array}{c}0.15 \\
(1.20)\end{array}$ & $\begin{array}{c}0.02 \\
(0.02)\end{array}$ & $\begin{array}{l}0.36^{*} \\
(1.65)\end{array}$ & $\begin{array}{c}0.83^{* * * *} \\
(6.80)\end{array}$ \\
\hline $\begin{array}{l}\text { Year Fixed } \\
\text { Host Country Fixed }\end{array}$ & $\begin{array}{l}\text { YES } \\
\text { YES }\end{array}$ & $\begin{array}{l}\text { YES } \\
\text { YES }\end{array}$ & $\begin{array}{l}\text { YES } \\
\text { YES }\end{array}$ & $\begin{array}{l}\text { YES } \\
\text { YES }\end{array}$ & $\begin{array}{l}\text { YES } \\
\text { YES }\end{array}$ & $\begin{array}{l}\text { YES } \\
\text { YES }\end{array}$ \\
\hline Constant & $\begin{array}{c}-7.71 * * * * \\
(-3.58) \\
\end{array}$ & $\begin{array}{c}-4.33 * * * \\
(-5.20) \\
\end{array}$ & $\begin{array}{c}-9.61 * * * \\
(-2.59) \\
\end{array}$ & $\begin{array}{c}-3.82 * * * \\
(-3.84) \\
\end{array}$ & $\begin{array}{c}-9.50 * * * \\
(-2.62)\end{array}$ & $\begin{array}{c}-4.65 * * * \\
(-3.40) \\
\end{array}$ \\
\hline $\begin{array}{l}\text { Adjusted } \mathrm{R}^{2} \\
\text { Observations }\end{array}$ & $\begin{array}{l}0.31 \\
5291\end{array}$ & $\begin{array}{r}0.33 \\
8811\end{array}$ & $\begin{array}{l}0.29 \\
3682\end{array}$ & $\begin{array}{r}0.36 \\
5721\end{array}$ & $\begin{array}{l}0.30 \\
1609\end{array}$ & $\begin{array}{c}0.35 \\
3090\end{array}$ \\
\hline
\end{tabular}




\section{Appendix 3 - Bond Foreign Bias During Eurozone Debt Crisis and Global Financial Crisis - from non-EMU source countries}

This table shows regression results of foreign bias (FBIAS) from non-EMU source countries to all host countries. The dependent variable is FBIAS, the log ratio of the share of a host country (country j) in bond holdings of a source country (country i) to the world bond market weight of country $j$. GIIPSCr is an interaction term of ECrisis and GIIPS. ECrisis is a dummy variable of 1 for Eurozone crisis years 2009 - 2011 and GIIPS is a dummy variable of 1 for five Eurozone crisis countries namely Greece, Italy, Ireland, Portugal and Spain (GIIPS), 0 otherwise. EuZC $r$ is an interaction term of ECrisis and EZone. EZone is a dummy variable of 1 for all countries within the European Monetary Union, 0 otherwise. GCrisis is a dummy a $(C R I S K)$. Fali and maculinity (MASC) of sols results with the stance shown in parenthesis.

Model I

All Countries

$-0.75^{* * *}$

ECrisis

GCrisis

EuZCr

EZone

GIIPSCr

GIIPS

EXCH

BDEV

PROP

CAPOP

CRISK

DIST

COMLA

BILTR

UNTAV

MASC

INSB

Constant

Adjusted R

Observations

(15.98)

$-4.15 * * *$

0.33

Model II

nteraction with EMU

$-0.64 * * * *$

$(-3.33)$

$0.27 *$
$(1.67)$

$-0.53 *$

$(-1.82)$

$0.76^{* * * *}$

(3.52)

Model III

nteraction with GIIPS

$-0.64 * * *$

$(-3.84)$

0.30
$(1.62)$

$(-1.80)$

$-0.44 *$

$(-1.70)$

.05**

(2.92)

$(-38$ *

$(-2.34)$

(8.96)

0.11

(2.53)

$0.05^{*}$

(1.83)

$-0.19^{* *}$

$(-2.48)$

$-1.90 * * *$

(-26.03)

$1.36 * * *$

(8.55)

$0.03 .13)$

(3.13)

$-0.07 * * *$
$(-25.86)$

$0.02 * * *$

(7.18)

$0.59 * * *$

(16.00)

$-4.24 * * *$
$(-7.76)$

0.33 


\section{Appendix 4 - Bond Foreign Bias During Eurozone Debt Crisis and Global Financial Crisis - from EMU source countries}

the world bond market weight of country . GIPSS) 0 or in 1 for Global Financil crisis years 2007 - 2008: 0 otherwise. Other regressors include: i) Economic Fundamentals for host country $j$ and ii) bilateral and investor-specific Familiarity Factors. Economic Fundamentals include annual yield on long-term government bonds (YLD) net of inflation and sovereign risk, log (natural) of exchange rate volatility (EXCH), log of bond market development (BDEV), protection of property rights (PROP), capital openness (CAPOP), and country risk (CRISK). Familiarity Factors include log of kilometer distance between countries (DIST), common language (COMLA) dummy, average bilateral trade weight assigned by partner countries (BILTR), uncertainty avoidance (UNTAV) of source country, and masculinity (MASC) of source country. INSB equals one minus home bias of source country $i$ and controls for the obvious impact of country $i$ 's domestic bias. All variables are constructed or sourced as reported in Table 1. All models report results with the standard errors corrected for heteroscedasticity at panel level using White (1980) method. Data is for years 2001 to 2012. Statistical significance is reported against 10\% (*), 5\% (**) and $1 \%(* * *)$ significance levels. $t$-statistics are shown in parenthesis.

Model I Model II Model III

\begin{tabular}{|c|c|c|c|}
\hline & $\begin{array}{c}\text { Model I } \\
\text { All Countries }\end{array}$ & $\begin{array}{c}\text { Model II } \\
\text { Interaction with EMU }\end{array}$ & $\begin{array}{c}\text { Model III } \\
\text { Interaction with GIIPS }\end{array}$ \\
\hline \multirow[t]{2}{*}{ ECrisis } & $-0.73 * * *$ & $-1.11^{* * * *}$ & $-0.75^{* * *}$ \\
\hline & $(-4.15)$ & $(-4.77)$ & $(-3.90)$ \\
\hline \multirow{2}{*}{ GCrisis } & 0.02 & -0.01 & -0.03 \\
\hline & $(0.10)$ & $(-0.06)$ & $(-0.19)$ \\
\hline \multirow[t]{2}{*}{ EZone } & & $\begin{array}{l}(1.75) \\
1.90 * * *\end{array}$ & \\
\hline & & $(9.85)$ & \\
\hline GIIPSCr & & & $\begin{array}{l}-0.13^{*} \\
(-171)\end{array}$ \\
\hline \multirow[t]{2}{*}{ GIIPS } & & & $1.65 * * *$ \\
\hline & & & $(8.99)$ \\
\hline \multirow{2}{*}{ YLD1 } & $0.04 * *$ & $0.03 *$ & $0.04 *$ \\
\hline & $(2.01)$ & $(1.88)$ & $(1.86)$ \\
\hline \multirow[t]{2}{*}{$\mathrm{EXCH}$} & $-0.60 * * *$ & $-0.41 * *$ & $-0.31 * *$ \\
\hline & $(-3.49)$ & $(-2.40)$ & $(-2.22)$ \\
\hline \multirow[t]{2}{*}{ BDEV } & $0.57 * * *$ & $0.47 * * *$ & $0.40^{* * * *}$ \\
\hline & $(6.81)$ & $(5.54)$ & $(4.53)$ \\
\hline \multirow[t]{2}{*}{ PROP } & $0.10^{*}$ & $0.08^{*}$ & $0.07 *$ \\
\hline & $(1.78)$ & $(1.91)$ & $(1.74)$ \\
\hline \multirow[t]{2}{*}{ CAPOP } & $0.02 *$ & $0.01 *$ & $0.03 *$ \\
\hline & $(1.87)$ & $(1.71)$ & $(1.88)$ \\
\hline \multirow[t]{2}{*}{ CRISK } & $-0.11^{*}$ & $-0.15^{* *}$ & $-0.12 *$ \\
\hline & $(-1.77)$ & $(-2.03)$ & $(-1.91)$ \\
\hline \multirow[t]{2}{*}{ DIST } & $-1.69 * * *$ & $-1.47 * * *$ & $-1.61 * * *$ \\
\hline & $(-21.63)$ & $(-19.90)$ & $(-21.07)$ \\
\hline \multirow{2}{*}{ COMLA } & $0.98^{* * *}$ & $0.55^{* * * *}$ & $0.71 * * *$ \\
\hline & $(4.82)$ & $(2.88)$ & $(3.68)$ \\
\hline \multirow[t]{2}{*}{ BILTR } & 0.00 & $0.03 * * *$ & 0.01 \\
\hline & $(0.48)$ & $(3.33)$ & $(0.68)$ \\
\hline \multirow[t]{2}{*}{ UNTAV } & $-0.05^{* * *}$ & $-0.05^{* * * *}$ & $-0.05^{* * *}$ \\
\hline & $(-14.46)$ & $(-14.67)$ & $(-14.48)$ \\
\hline \multirow{2}{*}{ MASC } & $0.02 * * *$ & $0.02 * * *$ & $0.02 * * *$ \\
\hline & $(5.81)$ & $(5.85)$ & $(5.86)$ \\
\hline \multirow[t]{2}{*}{ INSB } & $0.31 * * *$ & $0.32 * * *$ & $0.32 * * *$ \\
\hline & $(5.86)$ & $(6.10)$ & $(6.05)$ \\
\hline Host Country Fixed & YES & YES & YES \\
\hline \multirow{2}{*}{ Constant } & $-1.89 * * *$ & 0.66 & $-1.79 * * *$ \\
\hline & $(-3.28)$ & $(0.98)$ & $(-3.08)$ \\
\hline Adjusted $\mathrm{R}^{2}$ & 0.44 & 0.44 & 0.44 \\
\hline Observations & 4353 & 4353 & 4353 \\
\hline
\end{tabular}




\section{Appendix 5- Bond Foreign Bias During Eurozone Debt Crisis and Global Financial Crisis - All countries to non-EMU}

This table shows regression results of foreign bias (FBIAS) from all source countries to non-EMU host countries. The dependent variable is FBIAS, the log ratio of the share of a host country (country $j$ ) in bond holdings of a source country (country $i$ ) to the world bond market weight of country j. ECrisis is a dummy variable of 1 for Eurozone crisis years $2009-2011$. GCrisis is a dummy variable of 1 for Global Financial crisis years 2007 - 2008; 0 otherwise. Other regressors include: i) Economic Fundamentals for host country $j$ and ii) bilateral and investor-specific Familiarity Factors. Economic Fundamentals include annual yield on long-term government bonds $(Y L D)$ net of inflation and sovereign risk, $\log$ (natural) of exchange rate volatility (EXCH), log of bond market development (BDEV), protection of property rights $(P R O P)$, capital openness $(C A P O P)$, and country risk (CRISK). Familiarity Factors include log of kilometer distance between countries (DIST), common language (COMLA) dummy, average bilateral trade weight assigned by partner countries (BILTR), uncertainty avoidance (UNTAV) of source country, and masculinity (MASC) of source country. INSB equals one minus home bias of source country $i$ and controls for the obvious impact of country $i$ 's domestic bias. All variables are constructed or sourced as reported in Table 1. All models report results with the standard errors corrected for heteroscedasticity at panel level using White (1980) method. Data is for years 2001 to 2012. Statistical significance is reported against $10 \%(*), 5 \%(* *)$ and $1 \%(* *)$ significance levels. $t$-statistics are shown in parenthesis.

\begin{tabular}{|c|c|}
\hline & $\begin{array}{c}\text { Model I } \\
\text { Non-EMU host countries }\end{array}$ \\
\hline ECrisis & $\begin{array}{c}-0.81 * * * \\
(-5.09)\end{array}$ \\
\hline GCrisis & $\begin{array}{c}0.14 \\
(0.88)\end{array}$ \\
\hline YLD & $\begin{array}{l}0.04 * * \\
(2.57)\end{array}$ \\
\hline $\mathrm{EXCH}$ & $\begin{array}{l}-0.42 * * \\
(-2.11)\end{array}$ \\
\hline BDEV & $\begin{array}{c}0.62 * * * \\
(9.02)\end{array}$ \\
\hline PROP & $\begin{array}{c}0.06 * * \\
(2.09)\end{array}$ \\
\hline CAPOP & $\begin{array}{l}0.02 * \\
(1.87)\end{array}$ \\
\hline CRISK & $\begin{array}{c}-0.11 * * \\
(-2.33)\end{array}$ \\
\hline DIST & $\begin{array}{c}-1.98 * * * \\
(-29.60)\end{array}$ \\
\hline COMLA & $\begin{array}{c}1.00 * * * \\
(6.06)\end{array}$ \\
\hline BILTR & $\begin{array}{c}0.02 * * \\
(2.36)\end{array}$ \\
\hline UNTAV & $\begin{array}{c}-0.06 * * * \\
(-21.06)\end{array}$ \\
\hline MASC & $\begin{array}{c}0.02 * * * \\
(6.32)\end{array}$ \\
\hline INSB & $\begin{array}{c}0.96 * * * \\
(24.44)\end{array}$ \\
\hline Host Country Fixed & YES \\
\hline Constant & $\begin{array}{c}-0.61 \\
(-1.07) \\
\end{array}$ \\
\hline $\begin{array}{l}\text { Adjusted } \mathrm{R}^{2} \\
\text { Observations }\end{array}$ & $\begin{array}{l}0.33 \\
9521\end{array}$ \\
\hline
\end{tabular}


Appendix 6 - Bond Foreign Bias During Eurozone Debt Crisis and Global Financial Crisis - All countries to EMU

This table shows regression results of foreign bias (FBIAS) from all source countries to EMU host countries. The dependent variable is FBIAS, the log ratio of the share of a host country (country $j$ ) in bond holdings of a source country (country i) to the world bond market weight of country j. GIIPSCr is an interaction term of ECrisis and GIIPS. ECrisis is a dummy variable of 1 for Eurozone crisis years 2009 - 2011 and GIIPS is a dummy variable of 1 for five Eurozone crisis countries namely Greece, Italy, Ireland, Portugal and Spain (GIIPS), 0 otherwise. GCrisis is a dummy variable of 1 for Global Financial crisis years 2007 - 2008; 0 otherwise. Other regressors include: i) Economic Fundamentals for host country $j$ and ii) bilateral and investor-specific Familiarity Factors. Economic Fundamentals include annual yield on long-term government bonds ( $Y L D$ ) net of inflation and sovereign risk, log (natural) of exchange rate volatility (EXCH), log of bond market development $(B D E V)$, protection of property rights (PROP), capital openness (CAPOP), and country risk (CRISK). Familiarity Factors include log of kilometer distance between countries (DIST), common language (COMLA) dummy, average bilateral trade weight assigned by partner countries (BILTR), uncertainty avoidance (UNTAV) of source country, and masculinity (MASC) of source country. INSB equals one minus home bias of source country $i$ and controls for the obvious impact of country $i$ 's domestic bias. All variables are constructed or sourced as reported in Table 1. All models report results with the standard errors corrected for heteroscedasticity at panel level using White (1980) method. Data is for years 2001 to 2012. Statistical significance is reported against $10 \%(*), 5 \%(* *)$ and $1 \%(* * *)$ significance levels. $t$-statistics are shown in parenthesis.

\begin{tabular}{|c|c|c|}
\hline & $\begin{array}{c}\text { Model I } \\
\text { EMU Countries }\end{array}$ & $\begin{array}{c}\text { Model II } \\
\text { Interaction with GIIPS }\end{array}$ \\
\hline \multirow[t]{2}{*}{ ECrisis } & $-1.20 * * *$ & $-1.10 * * *$ \\
\hline & $(-5.80)$ & $(-4.16)$ \\
\hline \multirow{2}{*}{ GCrisis } & 0.18 & 0.25 \\
\hline & $(0.87)$ & $(1.23)$ \\
\hline \multirow[t]{2}{*}{ GIIPSCr } & & $-0.36^{*}$ \\
\hline & & $(-1.95)$ \\
\hline \multirow[t]{2}{*}{ GIIPS } & & 0.44 \\
\hline & & $(1.36)$ \\
\hline \multirow[t]{2}{*}{ YLD } & 0.03 & 0.03 \\
\hline & $(1.39)$ & $(1.53)$ \\
\hline \multirow[t]{2}{*}{ EXCH } & -0.18 & -0.10 \\
\hline & $(-0.51)$ & $(-0.28)$ \\
\hline \multirow[t]{2}{*}{ BDEV } & $0.90 * * *$ & $0.86^{* * *}$ \\
\hline & $(6.61)$ & $(6.04)$ \\
\hline \multirow[t]{2}{*}{ PROP } & $0.35 * * *$ & $0.45 * * *$ \\
\hline & $(4.43)$ & $(3.91)$ \\
\hline \multirow[t]{2}{*}{ CAPOP } & $0.10 * *$ & $0.10 * *$ \\
\hline & $(2.46)$ & $(2.50)$ \\
\hline \multirow[t]{2}{*}{ CRISK } & $-0.70 * * *$ & $-0.71 * * *$ \\
\hline & $(-5.65)$ & $(-5.71)$ \\
\hline \multirow[t]{2}{*}{ DIST } & $-2.27 * * *$ & $-2.27 * * *$ \\
\hline & $(-26.11)$ & $(-26.22)$ \\
\hline \multirow[t]{2}{*}{ COMLA } & 0.30 & 0.36 \\
\hline & $(1.22)$ & $(1.43)$ \\
\hline \multirow[t]{2}{*}{ BILTR } & $0.04 * * *$ & $0.03 * * *$ \\
\hline & $(3.40)$ & $(2.95)$ \\
\hline \multirow[t]{2}{*}{ UNTAV } & $-0.03 * * *$ & $-0.03 * * *$ \\
\hline & $(-8.71)$ & $(-8.81)$ \\
\hline \multirow[t]{2}{*}{ MASC } & $0.02 * *$ & $0.02 * *$ \\
\hline & $(2.19)$ & $(2.25)$ \\
\hline \multirow[t]{2}{*}{ INSB } & $0.48 * * *$ & $0.48 * * *$ \\
\hline & $(10.01)$ & $(9.91)$ \\
\hline Host Country Fixed & YES & YES \\
\hline \multirow[t]{2}{*}{ Constant } & $-6.03 * * *$ & $-7.17 * * *$ \\
\hline & $(-3.85)$ & $(-4.05)$ \\
\hline Adjusted $\mathrm{R}^{2}$ & 0.32 & 0.32 \\
\hline Observations & 4581 & 4581 \\
\hline
\end{tabular}

